ISSN: 2146-3042

DOI: $10.25095 /$ mufad.710354

\title{
Katılım Esasına Dayalı Bireysel Emeklilik Fonlarının Performans
} Analizi*

\author{
Melek BAYRAKTAR** \\ Mine AKSOY***
}

\section{ÖZET}

Katılım esasına dayalı fon portföyü, kira sertifikaları, katılma hesapları, ortaklık paylarl, altın ve diğer kıymetli madenler ile Sermaye Piyasası Kurulunca uygun görülen diğer faize dayalı olmayan para ve sermaye piyasası araçlarından oluşmaktadır. Bu çalışmanın birinci amacı katılım esasına dayalı bireysel emeklilik yatırım fonlarının performanslarını analiz etmektir. İinci amacı, bu fonların yöneticilerinin portföy seçicilik ve piyasa zamanlama yeteneğini ölçmektir. Üçüncü amacı ise fon getirilerinin politik krizlerden etkilenip etkilenmediğinin araştırılmasıdır. Analiz sonuçları bu fonlarının performanslarının başarısız olduğunu ve fon yöneticilerinin seçicilik ve piyasa zamanlama yeteneklerinin olmadığını göstermiştir. Ayrıca altına dayalı sermaye piyasası araçlarından oluşan katılım esasına dayalı emeklilik yatırım fonlarının krizden etkilenmediği, diğer fonların ise krizden negatif etkilendiği tespit edilmiştir.

Anahtar Kelimeler: Katılım Bankacılı̆̆l, Emeklilik Fonları, Seçicilik, Piyasa Zamanlaması, Kriz, Altın.

JEL Sınıflandırması: G1, G14, G18.

\section{Performance Analysis Of Pension Funds Based On Participation Basis}

\section{ABSTRACT}

Fund type based on participation is composed of rent certificates, participation accounts, partnership shares, gold and other precious metals and other interest-free Money and capital market instruments deemed appropriate by the Capital Markets Board. The first objective of this study is to analyze the performance of participation-based pension investment funds. These condobjective is to measure the timing and selectivity ability of the fund managers. The third objective of thestudy is toinvestigatewhetherthefundperformance is affectedbypoliticalcrises. Theresults of the analysis showed that the performance of these funds was poor and that fund managers lacks electivity and market timing capabilities. The participation-based pension investment funds, which consist of gold-based capital market instruments, were not affected by the crisis, while other funds were negatively affected by the crisis.

Keywords: ParticipationBanking, PensionFunds, Selectivity, Market Timing, Crisis, Gold.

Jel Classification: $G 1, G 14, G 18$.

\footnotetext{
* Bu çalışma Yalova Üniversitesi Sosyal Bilimler Enstitüsü İşletme Anabilim Dalı'nda Doç. Dr. Mine Aksoy Kavalcı danışmanlığında Melek Bayraktar tarafından “Türkiye'de Katılım Esasına Dayalı Bireysel Emeklilik Fonlarının Performans Analizi” ismiyle tamamlanarak 26.06.2019 tarihinde savunulan yüksek lisans tezinden türetilmiştir.

Makale Gönderim Tarihi: 16.07.2019, Makale Kabul Tarihi: 08.09.2019, Makale Türü: Araştırma Makalesi ** byrktr_155@hotmail.com, Orcid ID: 0000-0002-8549-5991.

*** Doç. Dr., Yalova Üniversitesi, İktisadi ve İdari Bilimler Fakültesi, maksoy@yalova.edu.tr, Orcid ID: 00000002-4773-1770.
} 


\section{GíRiş}

Emeklilik yatırım fonu, emeklilik şirketi tarafından emeklilik sözleşmesi çerçevesinde tahsil edilen ve katılımcılar adına bireysel emeklilik hesaplarında izlenen katkıların değerlendirilmesi amacıyla oluşturulan bir yatırım fonudur. Fon, portföy yönetim şirketlerince yönetilmektedir ${ }^{1}$. Emeklilik yatırım fonlarının başarısında portföy seçimi büyük önem arz etmektedir. 1952 yılında Markowitz tarafından geliştirilen Modern Portföy Teorisine göre portföy seçiminde ilk aşama gözlem ve tecrübe ile başlamakta ve portföyde bulunan menkul kıymetlerin performanslarının gelecekte başarılı olacağı inancı ile sona ermektedir (Markowitz, 1952:77). Bu teori, yatırımcının en yüksek getiriyi sağlayan ve en az risk seviyesine sahip menkul kıymetlerin bulunduğu portföyü tercih ettiği takdirde, risk yükseldikçe yatırımcı için beklenen getirinin artacağını öngörmektedir.

Bireysel yatırımcılardan elde edilecek tasarrufların uzun vadede yatırıma dönüşmesini ve bu yatırıma dönüşen kaynakların bireylere emeklilik döneminde ek gelir elde etmeyi sağlayacak, özel ve tamamlayıcı emeklilik sistemi olan bireysel emeklilik sistemi (BES), 27.10.2003 tarihinde yürürlüğe girmiştir. Bireysel emeklilik sisteminde uzun vadede fon kaynağı yaratılması fon şirketleri tarafından kurulan emeklilik yatırım fonları ile sağlanmaktadır. BES'in yürürlüğe girdiği tarihten bu zamana kadar 266 emeklilik yatırım fonu faaliyete başlamıştır.

Katılım bankacılığına dayalı bireysel emeklilik sistemi 12/01/2008 tarihli resmi gazete değişikliyle ${ }^{2}$ yatırım fonlarında en az \%30 devlet tahvili ve hazine bonosu bulundurma şartının kardırılmasıyla Türkiye'de işlerlik kazanmaya başlamıştır (Kaya, 2013: 52) Bu şartın kaldırılması, faizsiz enstrümana dayalı yatırım fonlarının katılım bankaları ve diğer mevduat bankaları tarafından oluşturulmasının önünü açmıştır. Faizden dolayı yatırım yapmak istemeyen müşterilerin tasarrufları yatırıma dönüşmeye başlamıştır. 29.12.2012 tarihinde yürürlüğe giren Bireysel Emeklilik Sisteminde Devlet Katkısı Hakkında Yönetmelik ile birlikte 01.01.2013 tarihi itibariyle emeklilik yatırım fonlarına \%25 devlet katkısı ve vergisel teşvikler getirilmiştir ${ }^{3}$. Devlet tarafından getirilen bu teşvikler, kamu bankalarında ve diğer özel bankalarda katılım bankacılı̆̆ı esasına yönelik emeklilik yatırım fonlarının sayısının artmasını sağlamıştır.

Murabaha (maliyetine kar konularak satış), mudarebe (emek-sermaye ortaklı̆̆ı), müşareke (kar-zarar ortaklığı), sukuk (kira sertifikası, varlık senedi), selem (ileriye dönük mal satın alımı veya mal satışı, peşin para veresiyeli satış), icara (kiralama), karz-ı hasen (güzel borç, faizsiz borç), istisna (siparişe dayalı satın alma), teverruk (uluslararası kar marjlı satış), tekafül (islami sigortacılık)İslami fon kullandırma yöntemlerine örnektir. Katılım esasına dayalı emeklilik yatırım fonları bu yöntemlere dayandırılarak çıkarılmış olan, kira sertifikaları, katılma hesapları, ortaklık payları, altın ve diğer kıymetli madenler ile Sermaye Piyasası Kurulunca uygun görülen diğer faize dayalı olmayan para ve sermaye piyasası araçlarından oluşmaktadır.

\footnotetext{
${ }^{1}$ https://www.egm.org.tr/bireysel-emeklilik/emeklilik-yatirim-fonlari, Erişim tarihi: 13.06.2019.

${ }^{2} \mathrm{http} / / /$ www.resmigazete.gov.tr/eskiler/2008/01/20080112-8.htm, Erişim: 13.06.2019.

${ }^{3} \mathrm{http}: / / w w w . r e s m i g a z e t e . g o v . t r / e s k i l e r / 2012 / 12 / 20121229-7 . h t m$, Erişim: 13.06.2019.
} 
Bu fon türü Türkiye'de 2013 yılından sonra gelişim göstermeye başladığından dolayı katılım bankacılığı esasına dayalı bireysel emeklilik fonları ile ilgili çok fazla çalışma yapılmamıştır. Bu çalışmanın amacı katılım esasına dayalı emeklilik yatırım fonlarının performanslarının karşılaştırmalı olarak analiz edilmesi ve bu fonların politik kriz karşısında nasıl bir davranış sergilediğinin araştırılmasıdır.

İncelediğimiz dönem aralığında 15.07.2016 tarihinde gerçekleşen başarısız darbe girişimi bir politik kriz olarak kabul edilmiş ve bu krizin katılım esasına dayalı fonların getirileri üzerindeki etkisi olay etüdü yöntemi ile analiz edilmiştir. Son olarak da Türkiye'de katılım esasına dayalı emeklilik yatırım fonlarının yöneticilerinin seçicilik ve piyasa zamanlama yeteneği, Treynor-Mazuy tarafindan bulunan kuadratik regresyon yöntemi ile analiz edilmiştir. Bu çalışmanın önceki çalışmalardan ilk farkı fon şirketi, fon türü, kamu özel şirket ayrımı ve risk türlerine göre fon performansları arasında bir fark olup olmadığının istatistiksel testler ile analiz edilmesidir. İkinci önemli farkı ise ilk defa politik krizin katılım esasına dayalı fonların getirileri üzerindeki etkisinin analiz edilmesidir.

\section{KAVRAMSAL ÇERÇEVE}

Yatırım fonlarının performans analizleri 1965 yılında Jack L. Treynor tarafından geliştirilen Treynor Endeksi, 1966 yılında William F. Sharpe tarafından geliştirilen Sharpe Endeksi, 1968 yılında Michael C. Jensen tarafindan geliştirilen Jensen Alfa Endeksi, 1997 yılında Franco Modigliani ve Leah Modigliani tarafından geliştirilen $\mathrm{M}^{2}$ Performans Ölçütü ve Treynor oranından geliştirilen $\mathrm{T}^{2}$ performans ölçütü ve değerleme oranı ile belirlenmiştir. Öncül kişilerin yaptığı çalışmalardaki ölçütler baz alınarak yatırım fonları ile ilgili Türkiye'de ve uluslararası alanda çalışmalar yapılmıştır.

Sharpe (1966), 1954-1963 yılları arasındaki 34 açık uçlu yatırım fonunun performansın1, piyasa getiri endeksi Dow-Jones Endeksinde bulunan 30 menkul kıymet getirisi ortalamasını baz alarak Sharpe oranı ile analiz etmiştir. Bu çalışmada 34 açık uçlu yatırım fonunun getirisinin piyasa getirisinin altında olduğu ve bu fonların performanslarının başarılı olmadığı sonucuna ulaşılmıştır.

McDonald (1967), 1964-1969 yılları arasında çeşitlendirilmiş 8 Fransız yatırım fonunun getirisinin piyasa getirisine göre performansını Sharpe Endeksi, Treynor Endeksi ve Jensen Alfası performans ölçütlerini kullanarak analiz etmiştir. Çalışmadaki araştırma sonucunda, 8 Fransız yatırım fonunun riske göre ayarlamış fonlar olduğu ve fonların getirisinin piyasa getirisinden daha fazla olduğu sonucu elde edilmiştir.

Kalkan (1992), Türkiye'de faaliyette olan, Ocak 1989-Nisan 1992 arası dönem için, 18 yatırım fonunun Sharpe Endeksi, Treynor Endeksi ve Jensen Alfa ölçütlerine göre performanslarını belirlemiş ve bu fonların Treynor-Mazuy ölçütlerine göre piyasa zamanlaması ve yatırım seçimini analiz etmiştir. Çalışmadaki araştırma sonucunda Türkiye'de faaliyet gösteren 18 yatırım fonunun performansı Türk pazar portföyüne göre başarısız bulunmuştur. Ayrıca fonların piyasa zamanlaması ve portföy yatırım seçim yeteneğinin de olmadığı sonucuna ulaşılmıştır.

Karacabey (1999), 1994-1997 y1llar1 arasında kesintisiz veriye sahip 31 adet A tipi fonun getirisinin pazar getirisine göre performanslarını Sharpe Endeksi, Treynor Endeksi ve 
Jensen Alfa ölçütlerini kullanarak belirlemiştir. Çalışmadaki araştırma sonucunda yatırım fonlarının performanslarının pazarın performansından daha düşük olduğu ve bu performans düşüklüğünün nedeninin fon yöneticilerinin seçicilik ve piyasa zamanlama yeteneğinin olmamasından kaynaklandığı sonucuna ulaşılmıştır.

Kılıç (2000), 1999-2001 yılları arasında faaliyette olan 75 A tipi ve 65 B tipi yatırım fonlarının performanslarını Sharpe Oranı, $\mathrm{M}^{2}$ ölçütü, Treynor Endeksi ve Değerleme oranı ölçütlerine göre belirlemiştir. Çalışmadaki araştırma sonucundabu iki fon türünün pazar portföyüne göre başarısız performans gösterdiği ve Treynor-Mazuy kuadratik regresyon modeli ve Merton-Henrkisson kukla değişkenli regresyon modeline göre bu fonları yöneten yöneticilerin piyasa zamanlama yeteneklerinin olmadığı sonucuna ulaşılmıştır.

Turan (2005), Türkiye'de faaliyette olan emeklilik yatırım fonlarının geçmiş performanslarını Sharpe Oranı ve $\mathrm{M}^{2}$ oranına göre analiz etmiştir. Çalışmadaki araştırma sonucunda emeklilik yatırım fonlarının düşük sistematik riske sahip olduğu ve emeklilik yatırım fonlarının genel olarak piyasa portföyüne göre başarılı performans göstermediği sonucuna ulaşılmıştır.

Dalğar (2006), 2004-2005 yılları arasında faaliyet gösteren bireysel emeklilik fonlarının getirilerinin piyasa getirisine göre performanslarını Sharpe Oranı, $\mathrm{M}^{2}$ performans ölçütü, Sortino Oranı, Treynor Oranı, $T^{2}$ performans ölçütlerine göre analiz etmiştir. Çalışmadaki araştırma sonucunda performansları hesaplanan bireysel emeklilik fonlarının piyasa getirisine göre düşük performansa sahip olduğu sonucuna ulaşılmıştır.

Abdullah vd (2007), Malezya'da 1992-2001 y1lları arasında faaliyette olan 14 İslami fon ve 41 geleneksel fonların performanslarını Sharpe Oran1, Treynor Oranı ve Jensen Alfası ölçütlerine göre belirlemiştir. Çalışmadaki araştırma sonucunda, geleneksel fonların İslami fonlardan daha iyi performans gösterdiği ancak 1997 krizinde İslami fonların geleneksel fonlardan daha üstün performans sağlamasından dolayı İslami fonların korunma amaçlı kullanılabileceği sonucuna ulaşılmıştır.

Korkmaz ve Uyguntürk (2007), 2004-2006 y1lları arasındaki 46 emeklilik fonunun performanslarını fon varlık çeşitlerinin pazar endeksine göre belirlemiştir. Çalışmadaki araştırma sonucunda emeklilik fonlarının getirisinin pazar endeks getirisinden daha düşük olduğu sonucuna ulaşılmıştır.

Taşcıyan (2009), Ocak 2004- Aralık 2007 yılları arasında faaliyette bulunan 58 emeklilik yatırım fonlarının performanslarını Sharpe Oranı, Treynor Oranı, Jensen Alfası performans ölçütlerine ve çoklu risk-getiri yaklaşımına dayalı Veri Zarflama Modeline göre analiz etmiştir. Çalışmadaki araştırma sonucunda fon performanslarının piyasa gösterge endeksinden daha düşük performansa sahip olduğu sonucuna ulaşılmıştır.

Mansor ve Bhatti (2011), Ocak 1990 ve Nisan 2009 dönemlerinde Malezya'da faaliyette olan 141 İslami ile 413 geleneksel yatırım fonunun Sharpe Oranı, Treynor ve Jensen Alfasına göre performanslarını belirlemiştir. Bu çalışmada 141 İslami ile 413 geleneksel yatırım fonunun performanslarının piyasa portföyü Kuala Lumpur Menkul Kıymetler Borsası endeksine göre oldukça başarılı olduğu ancak geleneksel yatırım fonlarının performanslarının İslami yatırım fonlarından daha iyi olduğu, İslami yatırım fon yöneticilerinin portföy seçicilik 
yeteneklerinin daha iyi olduğu, İslami ve geleneksel yatırım fonlarının piyasa zamanlama yeteneklerinin olduğu sonucuna ulaşılmıştır.

Shah vd. (2012), Pakistan'ın 35 İslami fonu ve 94 geleneksel fonunun performanslarını Sharpe Oranı, Treynor ve Jensen Alfasına göre analiz etmiştir. Çalışmadaki araştırma sonucunda İslami fonların düşük risk oranına sahip olduğu, geleneksel yatırım fonlarından daha iyi çeşitlendirildiği ve ortalama getirisinin piyasa getirisinden yüksek olduğu, geleneksel fonların getirisinin ise piyasa getirisinden düşük olduğu sonucuna ulaşılmıştır.

Ayaydın (2013), Ocak 2010- Ocak 2013 tarihleri arasındaki dönemde Türkiye'de faaliyet gösteren 34 adet esnek ve dengeli emeklilik yatırım fonunun performanslarını, Sharpe, Modigliani, Sortino Oranı ve sistematik riski esas alan Treynor, $\mathrm{T}^{2}$, Jensen performans endekslerine göre analiz etmiştir. Bu çalışmadaesnek ve dengeli emeklilik yatırım fonlarının performanslarının düşük olduğu ve bu başarısızlığın nedeninin portföy yöneticilerinin zamanlama yeteneği olduğu sonucuna ulaşılmıştır.

Kızılgeçit (2014), 2010-2012 yılları arasında faaliyet gösteren emeklilik yatırım şirketlerinin fon portföylerini yönetmede başarılı olup olmadığını veri zarflama yöntemiyle analiz etmiştir. Çalışmadaki araştırma sonucunda sadece 2 şirketin fon yönetiminde başarılı olduğu sonucuna ulaşılmış ve başarısız olan şirketlerin fon yönetimi konusunda başarılı şirketleri referans alarak fon yönetiminde başarı elde edebileceği konusunda kanaate varılmıştır.

Karabacak (2015), 2003-2013 yılları arasındaki dönemde Ordu Yardımlaşma Kurumu (OYAK) ile BES sisteminden elde edilen fon getirileri arasında anlamlı farklılık olup olmadığını Mann Whitney-U testi ile analiz etmiştir.Çalışmadaki araştırma sonucunda zorunlu ve gönüllü katılıma dayanan OYAK sistemi Türk Silahlı Kuvvetleri (TSK) 'nin kendi çalışanlarına $\% 5$ faiz getirisi sunduğu ancak BES sisteminin belirlenen kesin bir getirisinin olmadığı, getiri oranları karşılaştırıldığında OYAK sisteminin daha fazla getiri sağladığ sonucuna ulaşılmıştır.

Boovd (2017), 1996-2013 yılları arasında Malezya'da işlem gören geleneksel ve İslami yatırım fonlarının performanslarını Sharpe Endeksi, Treynor Endeksi ve Jensen Alfa ölçütlerini kullanarak analiz etmiştir. Çalışmadaki araştırma sonucunda kriz dönemlerinde İslami yatırım fonlarının geleneksel fonlardan daha başarılı olduğu ancak kriz döneminin dışında geleneksel fonların İslami fonlardan daha başarılı olduğu, çıkan sonucun şanstan kaynaklanmadığı, geleneksel fonların başarılı olmasının nedeninin holdinglerin özelliklerinden ve üstün risk yönetim yöntemlerinin varlığından kaynaklandığı sonucuna ulaşılmıştır.

Metin (2018), 2013-2015 yılları arasında faaliyet gösteren 23 aktif emeklilik yatırım fonu ile 20 pasif emeklilik yatırım fonunun performanslarını Sharpe Oranı, $\mathrm{M}^{2}$ performans Ölçütü, Sortino Oranı, Treynor Oranı, $\mathrm{T}^{2}$ performans ölçütlerine göre analiz etmiştir. Bu çalışmada pasif olan emeklilik yatırım fonlarının aktif olan emeklilik yatırım fonlarına (hisse senedi) göre yüksek performanslı olduğu, pasif olan emeklilik yatırım fonlarından endeks fonlarının borsa yatırım fonlarından daha yüksek performansa sahip olduğu sonucuna ulaşılmıştır. 
Saleck (2018), 2016 yılında faaliyette olan hisse senedi yoğun 15 yatırım fonunun performanslarını Sharpe Oranı, $\mathrm{M}^{2}$ performans ölçütü, Sortino Oranı, Treynor Oranı, $\mathrm{T}^{2}$ performans ölçütlerine göre analiz etmiştir. Hisse senedi yoğun fonların piyasa getirisinin altında getiri elde etmesi dolayısıyla bu fonların başarılı olmadığ sonucuna ulaşılmıştır.

Baykara (2018), 2014-2017 yılları arasında faaliyette olan geleneksel yatırım fonları ile İslami yatırım fonlarının performanslarını Sharpe Oranı, $\mathrm{M}^{2}$ performans ölçütü, Sortino Oranı, Treynor Oranı ve $\mathrm{T}^{2}$ performans ölçütlerine göre analiz etmiştir. Çalışmadaki araştırma sonucunda geleneksel yatırım fonlarının performansının İslami yatırım fonlarının performansından daha iyi olduğu, en başarısız yatırım fonlarının kira sertifikası ağırlığı yüksek olan İslami yatırım fonlarının olduğu sonucuna ulaşılmıştır.

Yatırım fonu yöneticilerinin seçicilik ve piyasa zamanlama yetenekleri 1966 yılında Jack L. Treynor ve Kay K. Mazur tarafından geliştirilen kuadratik regresyon modeli ile analiz edilmiştir. Öncül kişilerin yaptığı çalışmalardaki ölçütler baz alınarak fon yöneticilerin seçicilik ve piyasa zamanlama yeteneği ile ilgili Türkiye'de ve uluslararası alanda çalışmalar yapılmıştır. Treynor ve K.Mazuy (1966), kendi buldukları kuadratik regresyon modeline göre 1953-1962 yılları arasındaki 57 Dow-Jones Endeksi yatırım fonlarının yöneticilerinin seçicilik ve piyasa zamanlaması yeteneklerini analiz etmişlerdir. İncelenen fonların yöneticilerinin seçicilik ve piyasa zamanlama yeteneğinin olmadığ performanslarının başarılı olmadığı sonucuna ulaşılmıştır.

Jensen (1966), 1955-1964 yılları arasında Wiesenberger'in Yatırım Şirketlerinde bulunan 115 açık uçlu yatırım fonlarını yöneten fon yöneticilerinin seçicilik yeteneğini Jensen Alfası performans ölçütüne göre analiz etmiştir. İncelediği fonların fon yöneticilerinin fon portföyünü çeşitlendirmede yetersiz olduğu, bundan dolayı fonların performansının başarısız olduğu sonucuna ulaşılmıştır.

Henriksson (1984), 1968-1980 arası dönemlerdeki 116 açık uçlu yatırım fonu yöneticisinin piyasa zamanlama yeteneğini parametrik ve parametrik olmayan istatistiksel testler ile analiz etmiştir. Yatırım fonu yöneticilerinin, piyasa portföyünün getirisini başarılı yatırım stratejisi ile takip edemediklerinden dolayı, piyasa zamanlama yeteneklerinin olmadığı sonucuna ulaşılmıştır.

Akel (2007), 2000-2004 dönemlerindeki 51 A tipi ve 51 B tipi yatırım fonlarının performanslarını Sharpe, Treynor, Jensen performans ölçütlerine göre ve fon yöneticilerinin piyasa zamanlaması yeteneklerini Treynor-Mazuy ve Henriksson Merton yöntemlerine göre analiz etmiştir. A tipi fon yöneticilerinin hem seçicilik hem de piyasa zamanlaması yeteneğine sahip olmadığı, B tipi fon yöneticilerinin ise sadece seçicilik yeteneğine sahip olduğu ve yatırım fonlarının kısa dönemde performans devamlılığına sahip olduğu sonucuna ulaşılmıştır.

Merdad vd. (2010), 2003-2010 y1lları arasında Suudi Arabistan'da faaliyet gösteren HSBC'ye ait 28 geleneksel ve İslami yatırım fonlarının performansını Sharpe Oranı, Treynor Oranı, Jensen Alfası performans ölçütüne göre analiz etmiş ve bu fonların yöneticilerinin seçicilik ve piyasa zamanlaması yeteneklerini ölçmüştür. Çalışmadaki araştırma sonucunda HSBC'nin fon yöneticilerinin yükseliş ve finansal kriz dönemlerinde seçicilik yeteneğine sahip olduğu, HSBC'nin yükseliş dönemlerinde, geleneksel fonların yöneticilerinde seçicilik 
yeteneğinin daha yüksek olduğu, düşüş döneminde İslami fonları yöneten fon yöneticilerinin yeteneklerinin geleneksel fonları yöneten fon yöneticilerinin yeteneklerinden daha yüksek olduğu sonucuna ulaşılmıştır.

Tezcan (2012), 2004-2011 yılları arasında faaliyet gösteren 65 adet bireysel emeklilik fonlarının yöneticilerinin seçicilik ve piyasa zamanlama yeteneklerini analiz etmiştir. Bireysel emeklilik fonlarının sadece ikisinin başarılı olduğu ve fonların uzun vadede başarılı performans göstermediği ancak kısa vadede başarılı performans devamlılığ yöneticilerinin seçicilik özelliklerinin olmadığg sonucuna ulaşılmıştır.

Abdullah (2014), 1992-2001 yılları arasında Malezya'da faaliyet gösteren yatırım fonları, İslami fonlar, devlet fonları, sivil toplum fonları ve geleneksel fonların performanslarının başarılı olup olmamasında fon yöneticilerinin seçicilik ve piyasa zamanlama yeteneklerinin etkisinin olup olmadığını Sharpe Endeksi, Jensen Alfası ve piyasa zamanlama endeksi ölçüm yöntemlerini kullanarak analiz etmiştir. Çalışmadaki araştırma sonucundaİslami fonların geleneksel fonlardan daha iyi performans gösterdiği, fon yöneticilerinin piyasanın fiyat hareketlerini tahmin etmede ve fon çeşitlendirilmesinde yetersiz kaldığı sonucuna ulaşılmıştır.

Adalı ve Uysal (2017), 2014-2017 y1lları arasında faaliyet gösteren hisse senedi ağırlıklı 26 adet emeklilik yatırım fonunun performanslarını Sharpe Endeksi, Treynor Endeksi ve Jensen Alfası performans ölçütlerine ve bu fon yöneticilerinin piyasa zamanlama yeteneklerini kuadratik regresyon yöntemine göre analiz etmiştir. Çalışmadaki araştırma sonucunda İslami ölçüleri dikkate alan katılım emeklilik fonlarının piyasa göstergesinden daha iyi performans gösterdiği ancak geleneksel fonlardan daha başarısız olduğu ve hisse senedi ağırlıklı emeklilik yatırım fonlarının yöneticilerinin seçicilik ve piyasa zamanlamasında başarılı olduğu sonucuna ulaşılmıştır.

\section{ARASTTIRMANIN YÖNTEMI}

21.03.2019 tarihi itibariyle Kamuyu Aydınlatma Platformun (KAP)'da yayınlanan 266 bireysel emeklilik fonunun fon tüzükleri incelenmiş ve 53 fonun katılım esasına dayalı emeklilik fonu olduğu tespit edilmiştir. Örneklem sayısının eşit olma koşulunu sağlamak amacıyla 53 fon arasından 40 fon seçilmiştir. Bu fonların seçilme nedeni halka arz tarihlerinin 01.08.2014 tarihi öncesinde olmasıdır. Diğer 13 katılım bankacılığı esasına dayalı emeklilik yatırım fonu 2016 yılı ve sonrasında kurulmuş ve halka arz edilmiştir. Fonların 01.08.201428.02.2019 tarihleri arasındaki günlük birim fiyatları kullanılmıştır. Bu günlük birim fiyatlar Sermaye Piyasası Kurulunun ve Takasbank A.Ş'nin veri tabanından elde edilmiştir. Benckmark (Gösterge) endeksi olarak BIST 100 endeksi ile birlikte 40 fonun ortalamasi ile oluşturulan endeks ve risksiz faiz oranı olarak da BIST Bankalararası Gecelik Repo Faiz oranları kullanılmıştır. Bu veriler Türkiye Cumhuriyet Merkez Bankasının elektronik veri tabanından elde edilmiştir. Fon birim fiyatlarının logaritmik getirisi hesaplanarak analizler yapılmıştır. Fonların performansı Sharpe Oranı, Treynor Oranı, Jensen Alfası, $\mathrm{M}^{2}, \mathrm{~T}^{2}$ ve Değerleme Oranı ölçütleriyle hesaplanmış, bu oranların kamu-özel şirket, altın-kira sertifikasına dayalı varlık türü, fon şirketleri ve risk seviyelerine göre gruplara ayrılmış performans ölçütleri hesaplanmış, bu belirlenen gruplar arasında anlamlı fark olup olmadığı $\mathrm{t}$ testi, Anova Testi, Kruskal Wallis Testi, Mann Whitney U Testi yöntemleriyle EViews 10 ve IBM SPSS 21 istatistik paket programları aracılığıyla analiz edilmiştir. Çalışmanın 
devamında 15.07.2016 tarihinde gerçekleşen başarısız darbe girişimi bir politik kriz olarak kabul edilmiş ve bu krizin katılım esasına dayalı emeklilik fonlarının getirileri üzerindeki etkisi olay etüdü yöntemi ile analiz edilmiştir. Son olarak fon yöneticilerinin seçicilik ve piyasa zamanlama yeteneği Treynor-Mazuy kuadratik regresyon modeli ile test edilmiştir.

\subsection{Veri Analizi}

\subsubsection{Performans Değerleme Yöntemleri}

Getiri belli bir süre boyunca elde tutulan tasarruftan elde edilen kazanç veya kayıp olarak tanımlanabilir. Fonların ve endekslerin getiri hesaplanmasında normallik varsayımını sağlamak için logaritmik getiri hesaplanır. Logaritmik getiri şu şekilde hesaplanır (Tekbaş vd., 2014: 26).

$R_{t}=\ln \left(\frac{P_{\tau}}{P_{t-1}}\right)$

Risk ile belirsizlik kavramı genellikle aynı anlam içinde kullanılmaktadır. Ancak risk belirsizliğin sonucudur. Belirsizlik ise oluşabilecek sonuçların dağılımıdır. Risk beklenen sonuç ile gerçekleşen sonuç arasındaki farktır (Kurun, 2005: 3). Belirsizliğin olasılığı hesaplanamazken riskin olma ya da olmama olasılığ belirlenebilmektedir. Bundan dolayı belirsizlik rakamsal ifade edilemiyorken, risk rakamsal olarak ifade edilebilir ve ölçülebilmektedir. Finansal yatırım araçlarının performansını iki tür risk etkiler. Birincisi yatırım aracının bulunduğu pazara ait risktir ve tüm makro etkenlere açıktır. Bu risk sistematik risktir. İkinci risk türü ise sistematik olmayan risktir.Sistematik risk piyasa yönelik risk olduğundan tüm firmalar bu riskten etkilenmektedir. Bu riski kontrol altına almak oldukça zordur. Ancak tahmin edilebilir bir risktir. Bu risk emeklilik yatırım fonlarının performans analizlerinde $\beta$ katsayısı ile hesaplanır. Aşağıda formüle edilmiştir.

$$
\beta=\frac{\operatorname{Kovaryans}\left(R_{m,}, R_{p}\right)}{\operatorname{Varyanis} R_{m}}
$$

$\beta$ : Sistematik Risk $R_{m}$ : Pazar Portföyünün Getirisi $R_{p}$ : Fon Portföyünün Getirisi

Standart sapma fon getirilerinin ortalamadan ne kadar farklı olduğunu hesaplamak için kullanılır. Bu farklar ne kadar küçükse o fonun riski o kadar azdır. Standart sapmanın miktarı fondaki oynaklığın göstergesidir. Standart sapmanın formülü aşağıdaki gibidir.

$$
\sigma=\sqrt{\sum_{t=1}^{n} \frac{\left(R_{t}-R\right)^{2}}{n}}
$$

$\sigma$ : Standart Sapma $\bar{R}$ : Fonun Getirilerinin Ortalaması $R_{:}$: Fonunun $t$ günündeki Getirisi n: Gözlem Sayıs1

Yatırım fonlarının performanslarının ölçülmesini sağlayan yöntemlerden Sharpe Oranı, Treynor Oranı, Jensen Alfası, $\mathrm{M}^{2}, \mathrm{~T}^{2}$ ve Değerleme Oranı toplam riskin ölçümü olan standart sapma ve sistematik risk katsayısı $\beta$ baz alınarak hesaplanmaktadır. Sharpe Oranı ve 
$\mathrm{M}^{2}$ performans ölçütleri toplam risk katsayısı standart sapmaya, Treynor Oranı, Jensen Alfası, $\mathrm{T}^{2}$ ve Değerleme Oranı performans ölçütleri sistematik risk katsayısı $\beta$ 'ya göre belirlenmiştir.

Sharpe Oranı alınan birim risk başına elde edilen risksiz getiri üzerindeki getiriyi gösterir. Standart sapması düşük ve ortalama getirisi yüksek olan fonun Sharpe Oranı yüksektir. Sharpe oranının yüksek olması riske göre düzenlenmiş fonun performansının o kadar iyi olduğunu gösterir. Sharpe tarafindan geliştirilen ve portföyün performansını ölçmeye yarayan eşitlik şu şekilde gösterilir (Sharpe, 1966: 119-138).

$$
\text { Sharpe orani }=\frac{R_{p}-R_{p}}{\sigma_{p}}
$$

$\boldsymbol{R}_{p}$ : Fon Portföyünün Getirisi $\boldsymbol{R}_{f}$ : Risksiz Menkul Kıymetin Getirisi $\sigma_{p}$ : Portföyün Standart Sapmas1

F. Modigliani ve L. Modigliani tarafından geliştirilen ve standart sapmayı risk ölçütü olarak kullanan bir diğer performans ölçütü ise $\mathrm{M}$-kare ya da $\mathrm{M}^{2}$ performans ölçütüdür (Modigliani ve Modigliani, 1997: 45-54). M² ölçütü Sharpe Oranında olduğu gibi sadece portföy riskini değil aynı zamanda piyasa riskini de dikkate almaktadır (Teker vd., 2008: 94).

$$
M^{2}=R_{f}-R_{m}+\frac{\left(R_{p}-R_{f}\right)}{\sigma_{p}} * \sigma_{m} \text { yada } M^{2}=\operatorname{Sharpe} \approx \sigma_{m}+R_{f}-R_{m}
$$

$R_{p}$ : Fon Portföyünün Getirisi $R_{m}$ : Pazar Portföyünün Getirisi $R_{f}$ : Risksiz Menkul Kıymetin Getirisi $\sigma_{m}$ : Pazarın Toplam Riski $\sigma_{p}$ : Portföyün Toplam Riski

Treynor 1965 yılında yaptığı çalışmada menkul kıymet yatırım fonlarının çeşitlendirilerek ve uygun risk gruplarına göre ayrılarak sistematik olmayan riskin ortadan kaldırılabileceğini ifade etmektedir. Eğer sistematik olmayan risk sınıllandırılabilirse ya da tamamen yok edilirse fonun getirisi sistematik olmayan riske bağlı olarak analiz edilebilecektir (Korkmaz ve Uygurtürk, 2008: 120). Bundan dolayı Treynor performans ölçütü olarak portföyün toplam riskini değil sistematik risk olan Beta $(\beta)$ katsayısını kullanarak endeks belirlemiştir (Treynor, 1965: 63-75). Treynor Endeksine göre fonun portföy getirisi pazarın getirisinden yüksek olduğu durumlarda daha fazla getiri elde etmeyi sağlayacaktır.

$$
\text { Treynor Endekst }=\frac{R_{p}-R_{f}}{\beta_{p}}
$$

$R_{p}$ : Portföyün Getirisi $R_{f}$ : Risksiz Menkul Kıymetin Getirisi $\beta_{p}$ : Portföyün Sistematik Riski

Treynor Kare Performans Ölçütü Treynor endeksine portföyün risksiz faiz oranını ekleyerek risk düzeltilmesinin yapılmış halidir (Teker vd., 2008: 95). $T^{2}$ ölçütü Treynor endeksinin yüzdesel olarak belirtildiği performans ölçüm yöntemidir. Bu ölçüt aşağıdaki gibi hesaplanır: 


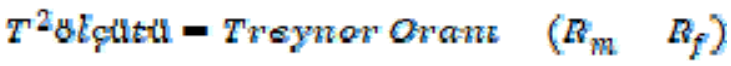

$$
\begin{aligned}
& R_{m} \text { : Pazar Portföyünün Getirisi } R_{f} \text { : Risksiz Menkul Kıymetin Getirisi }
\end{aligned}
$$

Michael C. Jensen tarafından 1968 yılında bulunan endeks fonların gösterge endeksine göre başarılı olup olmadığını analiz etmek için kullanılmıştır. Fon yöneticisi fon çeşitliliğini doğru belirlemişse alfa $(\alpha)$ değeri pozitif olacaktır. Eğer fon yöneticisi fon seçiminde başarısızsa alfa değeri negatif olacaktır. Bu endeks aşağıdaki formülle hesaplanmaktadır:

$$
\text { Fensen Alfast }(\alpha)=R_{p}-\left(R_{f}+\beta_{p} *\left(R_{m}-R_{f}\right)\right)
$$

$\boldsymbol{R}_{p}$ : Portföyün Getirisi $\boldsymbol{R}_{f}$ : Risksiz Menkul Kıymetin Getirisi $\boldsymbol{R}_{m}$ : Pazar Portföyünün Getirisi $\beta_{p}$ : Portföyün sistematik riski

Değerleme Oranı, Treynor ve Jensen Alfa ölçütünden farklı olarak sistematik olmayan riske göre performans düzeltmesi yapar. Değerleme oranına göre fon performansında sistematik riski farklı olan fonlar arasında farklı sonuçlar elde etmiştir. Değerleme oranı ne kadar yüksek olursa fon performansı daha yüksek olacaktır. Çünkü Jensen Alfası ( $\alpha$ )'sının yüksek olması fonun iyi çeşitlendirdiğinin göstergesi olacaktır.

$$
\text { Degerleme Qrom }=\frac{\text { Iensen Alfast }(\alpha)}{\text { Ststemattk Olmayan Rtsk }}
$$

\subsubsection{Fon Yöneticilerinin Seçicilik ve Piyasa Zamanlaması Performansının Kuadratik Regresyon Modeli ile Belirlenmesi}

Kuadratik regresyon modelinin ortaya çıkmasında amaç portföyün sistematik riskinin belirli bir zaman içinde değişkenlik gösterebileceği olasılığının tahmin edilmesidir. Bu model ilk defa 1966 yılında Treynor-Mazuy tarafından portföyün volatilitesinin (oynaklı̆̆ının) pazarın yüksek getiri sağladığı dönemin, pazarın düşük getiri sağladığı dönemden daha fazla mı sorusuna cevap bulmak için kullanılmıştır. Bu modelin eğimi yani $\beta$ faizden arındırılmış piyasa getirisi ile faizden arındırılmış portföy getirisi arasındaki ilişkiyi vermektedir. Ayrıca bu model portföy yöneticisi bu süreçte nasıl bir seçim yapmış ve bu yaptığı seçim uzun sürede başarılı olmuş mu sorularının cevabını da vermektedir. Eğer portföy yöneticisi portföyündeki hisse senetlerini iyi çeşitlendirmişse piyasa getirisi yüksek olduğu dönemde ona göre yüksek portföy getirisi, piyasa getirisi düşük olduğu dönemde ise en az kayıpla portföy getirisi elde edecektir. $\mathrm{Bu}$ da gösteriyor ki portföy yöneticisinin yapacağı seçimler ile sistematik risk kontrol altına alınabilecektir. Bu da portföy yöneticisinin piyasa zamanlama yeteneğini belirleyecektir. Treynor-Mazuy tarafından hesaplanan kuadratik regresyon modeli aşağıdaki gibidir: 


$$
R_{p}-R_{f}=\alpha+\beta \approx\left(R_{m}-R_{f}\right)+C *\left(R_{m}-R_{f}\right)^{2}+e_{p}
$$

$R_{p}$ : Fon Portföyünün Getirisini, $R_{m}$ : Pazar Portföyünün Getirisini, $R_{f}$ : Risksiz Menkul Kıymetin Getirisini, $\alpha$ : Fon Yöneticisinin Seçicilik Yeteneğini, $\beta$ : Fon Portföyünün Betasını, C: Fon Yöneticisinin Piyasa Zamanlama Yeteneğini göstermektedir.

\subsubsection{Olay Etüdü Yöntemi (Event Study)}

Katılım esasına dayalı bireysel emeklilik fonlarının günlük getirileri baz alınarak yapılan performans analizi çalışmamızın devamında, 15.07.2016 tarihinde Türkiye'de gerçekleşen politik krizin fonların getirilerinde anormal bir getiriye (AR) sebep olup olmadığ 1 analiz edilmiştir. Analizlerde Brown ve Warner (1985) tarafindan kullanılan düzeltilmiş ortalama getiri modeli (Mean Adjusted Model) kullanılmıştır. Olayın tarihi $t=0^{\prime}$ dır, etkinlik tarihine göre tahmin penceresi olarak tanımlanan, $\mathrm{t}=-90$ (T2) ile $\mathrm{t}=-10$ (T1) arasında, 80 günlük ortalama getiri hesaplanmaktadır. Olay periyodunun kendisi tahmin süresine dahil değildir. Gerçek getiri ile tahmin edilen ortalama getiri arasındaki fark, anormal getiri olarak adlandırılmaktadır (Brown ve Warner, 1985: 6).

$$
A R_{t t}=R_{t t}-\bar{R}
$$
Getirisi

$A R_{i t}:$ Fonun Anormal Getirisi $R_{t: t}$ :Fonun Gerçek Getirisi $\bar{R}$ :Fonun Tahmin Edilen

$$
\bar{R}=\frac{1}{\left(T_{2}-T_{1}+1\right)} \sum_{t=T_{1}}^{T 2} R_{t}
$$

SAR değişkeni $t$ gününde fonun istatistiksel olarak anlamlı bir anormal getiri oluşturup oluşturmadığını göstermektedir. $\% 5$ güven aralığı için $+/-1.96$ 'dan büyük bir değer istatistiksel olarak anlamlı bir anormal getiriyi ifade etmektedir.

$$
\begin{aligned}
& S A R_{i t}=\begin{array}{c}
A R_{t t} \\
S D\left(A R_{t i}\right)
\end{array} \\
& \sigma\left(A E_{i t}\right)=\sqrt{\frac{1}{T_{2}-T_{1}} \sum_{t=T_{n}}^{T_{n}} A R_{t t}^{2}}
\end{aligned}
$$

Tüm fonlar için ortalama anormal getiriler aşağıdaki formüle göre hesaplanmış, ortalama anormal getirilerinin istatiksel olarak anlamlı olup olmadığ $\mathrm{t}$ istatistiği ile analiz edilmiştir. $A A R_{t}$ değiş̧kenifonlarınortalama anormal getirisini ifade etmektedir.

$$
A A R_{t}=\frac{1}{N} \sum_{i=1}^{N} A R_{t i}
$$




$$
t_{i s t}=\frac{A A R_{t}}{\left(\sigma_{A R}\right) / \sqrt{N}}
$$

\subsection{Araştırmanın Bulguları ve Sonuçları}

Tablo 1 de analizlere dahil edilen katılım bankacılığı esasına dayalı emeklilik yatırım fonlarına ait bilgiler listelenmiştir.

Tablo 1. Katılım Esasına Dayalı 40 Emeklilik Yatırım Fonunun Tüzük Bilgileri

\begin{tabular}{|c|c|c|c|c|}
\hline $\begin{array}{l}\text { FON } \\
\text { KOD }\end{array}$ & FON İSMİ & $\begin{array}{l}\text { FONUN HALKA } \\
\text { ARZ TARİHI }\end{array}$ & $\begin{array}{c}\text { RÍSK } \\
\text { ORANI } \\
(1-7 \\
\text { ARASI } \\
\text { NDA }) \\
\end{array}$ & $\begin{array}{c}\text { YATIRIMCI } \\
\text { SAYISI } \\
(21.03 .2019 \\
\text { tarihi itibariyle) }\end{array}$ \\
\hline AEA & $\begin{array}{l}\text { ANADOLU HAYAT A.Ş. ALTIN KATILIM EMEKLİLİK YATIRIM } \\
\text { FONU }\end{array}$ & 30.04 .2013 & 6 & 346.312 \\
\hline AER & $\begin{array}{l}\text { ANADOLU HAYAT EMEKLİLIK A.Ş. KATILIM KATKI EMEKLİLİK } \\
\text { YATIRIM FONU }\end{array}$ & 30.04 .2013 & 2 & 27.358 \\
\hline AGE & $\begin{array}{c}\text { ANADOLU HAYAT EMEKLILIIK A.SS. KATILIM STANDART } \\
\text { EMEKLILIKK YATIRIM FONU }\end{array}$ & 30.11 .2010 & 2 & 57.207 \\
\hline AEL & $\begin{array}{l}\text { AVIVASA EMEKLİLIKK VE HAYAT A.S. ALTIN EMEKLİLIK } \\
\text { YATIRIM FONU }\end{array}$ & 7.08 .2013 & 5 & 340.107 \\
\hline HEA & $\begin{array}{l}\text { AXA HAYAT VE EMEKLILİK A.Ş. ALTIN KATILIM EMEKLİLİK } \\
\text { YATIRIM FONU }\end{array}$ & 1.10 .2013 & 6 & 11.655 \\
\hline HEE & $\begin{array}{l}\text { AXA HAYAT VE EMEKLILIIK A.Ş. KATILIM DEĞISSSKEN } \\
\text { EMEKLİLIK YATIRIM FONU }\end{array}$ & 1.10 .2013 & 4 & 1.804 \\
\hline HER & $\begin{array}{l}\text { AXA HAYAT VE EMEKLILIIK A.Ş. KATILIM KATKI EMEKLİLİK } \\
\text { YATIRIM FONU }\end{array}$ & 1.10 .2013 & 3 & 3.278 \\
\hline AGA & $\begin{array}{l}\text { BEREKET EMEKLILIIK VE HAYAT A.S. ALTIN KATILIM } \\
\text { EMEKLILILIK YATIRIM FONU }\end{array}$ & 7.05 .2013 & 6 & 54.565 \\
\hline AGB & $\begin{array}{c}\text { BEREKET EMEKLILIIK VE HAYAT A.S.S. BÜYÜME KATILIM } \\
\text { DEĞIŞKEN EMEKLILIK YATIRIM FONU }\end{array}$ & 5.06 .2012 & 5 & 24.597 \\
\hline AGD & $\begin{array}{l}\text { BEREKET EMEKLILIIK VE HAYAT A.Ş. KATILIM STANDART } \\
\text { EMEKLILIK YATIRIM FONU }\end{array}$ & 7.05 .2013 & 2 & 75.145 \\
\hline AGG & $\begin{array}{l}\text { BEREKET EMEKLIILIKK VE HAYAT A.Ş. KATILIM DEĞİSSKEN } \\
\text { GRUP EMEKLİLİK YATIRIM FONU }\end{array}$ & 12.06 .2012 & 4 & 49.453 \\
\hline $\mathrm{AGH}$ & $\begin{array}{l}\text { BEREKET EMEKLILIKK VE HAYAT A.Ş. KATILIM HISSE SENEDİ } \\
\text { EMEKLILIKK YATIRIM FONU }\end{array}$ & 28.05 .2012 & 6 & 68.240 \\
\hline AGM & $\begin{array}{l}\text { BEREKET EMEKLILIIK VE HAYAT A.S. MUHAFAZAKAR } \\
\text { KATILIM DEĞISSKEN EMEKLILIK YATIRIM FONU }\end{array}$ & 21.05 .2012 & 2 & 80.181 \\
\hline AGT & $\begin{array}{l}\text { BEREKET EMEKLİLIK VE HAYAT A.Ş. KATILIM KATKI } \\
\text { EMEKLILILIK YATIRIM FONU }\end{array}$ & 2.05 .2013 & 2 & 72.529 \\
\hline BNA & $\begin{array}{l}\text { BNP PARİBAS CARDİF EMEKLİLIKK ALTIN EMEKLİLIKK YATIRIM } \\
\text { FONU }\end{array}$ & 30.04 .2013 & 6 & 28.101 \\
\hline GEA & $\begin{array}{l}\text { GARANTİ EMEKLILIIK VE HAYAT A.S.S. KATILIM DINAMIK } \\
\text { DEĞISSKEN EMEKLILIIK YATIRIM FONU }\end{array}$ & 6.05 .2009 & 4 & 37.469 \\
\hline GES & $\begin{array}{l}\text { GARANTI EMEKLILLIK VE HAYAT A.Ş. KATILIM STANDART } \\
\text { EMEKLILIIK YATIRIM FONU }\end{array}$ & 26.06 .2013 & 2 & 22.314 \\
\hline GHA & $\begin{array}{l}\text { GARANTİ EMEKLILLIK VE HAYAT A.S. ALTIN EMEKLILIIK } \\
\text { YATIRIM FONU }\end{array}$ & 26.06 .2013 & 6 & 97.587 \\
\hline GHL & $\begin{array}{l}\text { GARANTİ EMEKLILIIK VE HAYAT A.Ş. KATILIM KATKI } \\
\text { EMEKLİLİK YATIRIM FONU }\end{array}$ & 2.05 .2013 & 2 & 58.805 \\
\hline HHA & $\begin{array}{l}\text { HALK HAYAT VE EMEKLILIIK A.SS. KATILIM KATKI EMEKLİLIK } \\
\text { YATIRIM FONU }\end{array}$ & 21.11 .2013 & 2 & 14.957 \\
\hline HHD & $\begin{array}{l}\text { HALK HAYAT VE EMEKLİLİK A.Ş. KATILIM STANDART } \\
\text { EMEKLİLIK YATIRIM FONU }\end{array}$ & 21.11 .2013 & 2 & 13.849 \\
\hline HHM & $\begin{array}{l}\text { HALK HAYAT VE EMEKLILLIK A.S. KATILIM HİSSE SENEDİ } \\
\text { EMEKLILIK YATIRIM FONU }\end{array}$ & 2.12.2013 & 5 & 1.765 \\
\hline HHN & $\begin{array}{c}\text { HALK HAYAT VE EMEKLİLIK A.Ş. KATILIM DİNAMIKK } \\
\text { DEĞİSSEN EMEKLILIIK YATIRIM FONU }\end{array}$ & 21.11 .2013 & 4 & 3.532 \\
\hline KEA & $\begin{array}{l}\text { KATILIM EMEKLILIIK VE HAYAT A.S. KATILIM KATKI } \\
\text { EMEKLİLIK YATIRIM FONU }\end{array}$ & 22.07 .2014 & 2 & 252.233 \\
\hline
\end{tabular}


Muhasebe ve Finansman Dergisi - Nisan/2020

(86): 153-184

\begin{tabular}{|c|c|c|c|c|}
\hline KEB & $\begin{array}{l}\text { KATILIM EMEKLİLİK VE HAYAT A.Ş. KATILIM STANDART } \\
\text { EMEKLİLIKK YATIRIM FONU }\end{array}$ & 16.07 .2014 & 2 & 253.793 \\
\hline $\mathrm{KEF}$ & $\begin{array}{l}\text { KATILIM EMEKLİLIK VE HAYAT A.Ş. ALTIN KATILIM } \\
\text { EMEKLİLIKK YATIRIM FONU }\end{array}$ & 16.07 .2014 & 6 & 122.579 \\
\hline KEG & $\begin{array}{l}\text { KATILIM EMEKLİLIKK VE HAYAT A.Ş. DENGELİ KATILIM } \\
\text { DEĞİSEN EMEKLİLİK YATIRIM FONU }\end{array}$ & 16.07 .2014 & 4 & 106.074 \\
\hline $\mathrm{KEH}$ & $\begin{array}{l}\text { KATILIM EMEKLİLIK VE HAYAT A.Ş. KATILIM HİSSE SENEDİ } \\
\text { EMEKLİLIKK YATIRIM FONU }\end{array}$ & 16.07 .2014 & 5 & 78.845 \\
\hline KEK & $\begin{array}{l}\text { KATILIM EMEKLİLİK VE HAYAT A.Ş. KATILIM DEĞİŞKEN GRUP } \\
\text { EMEKLİL̇K YATIRIM FONU }\end{array}$ & 23.07 .2014 & 3 & 44.849 \\
\hline MHA & $\begin{array}{l}\text { METLİFE EMEKLİLİK VE HAYAT A.Ş. KATILIM KATKI } \\
\text { EMEKLİLIKK YATIRIM FONU }\end{array}$ & 28.02 .2014 & 2 & 783 \\
\hline MHS & $\begin{array}{l}\text { METLİFE EMEKLİLİK VE HAYAT A.Ş. KATILIM STANDART } \\
\text { EMEKLİLIK YATIRIM FONU }\end{array}$ & 13.01 .2014 & 3 & 813 \\
\hline VEA & $\begin{array}{l}\text { VAKIF EMEKLİIIK VE HAYAT A.Ş. KATILIM DEĞİŞKEN GRUP } \\
\text { EMEKLİLIKK YATIRIM FONU }\end{array}$ & 15.02 .2012 & 3 & 451 \\
\hline VEB & $\begin{array}{l}\text { VAKIF EMEKLİLIKK VE HAYAT A.Ş. KATILIM DENGELİ } \\
\text { DEĞİŞKEN EMEKLILIK YATIRIM FONU }\end{array}$ & 23.02 .2012 & 4 & 76.921 \\
\hline VER & $\begin{array}{l}\text { VAKIF EMEKLİLIK VE HAYAT A.Ş. KATILIM KATKI EMEKLİLIK } \\
\text { YATIRIM FONU }\end{array}$ & 30.04 .2013 & 2 & 185.480 \\
\hline VEY & $\begin{array}{l}\text { VAKIF EMEKLİLIKK VE HAYAT A.Ş. KATILIM DİNAMİK } \\
\text { DEĞİSEEN GRUP EMEKLİLIK YATIRIM FONU }\end{array}$ & 27.10 .2010 & 4 & 4.528 \\
\hline VGA & $\begin{array}{l}\text { VAKIF EMEKLİLIK VE HAYAT A.Ş. ALTIN KATILIM EMEKLİLIK } \\
\text { YATIRIM FONU }\end{array}$ & 24.09 .2013 & 5 & 334.424 \\
\hline VGB & $\begin{array}{l}\text { VAKIF EMEKLİLIK VE HAYAT A.Ș. KATILIM STANDART } \\
\text { EMEKLİLIK YATIRIM FONU }\end{array}$ & 1.03 .2010 & 2 & 112.866 \\
\hline ZHA & $\begin{array}{l}\text { ZİRAAT HAYAT VE EMEKLİLIK A.Ş. KATILIM STANDART } \\
\text { EMEKLİLIKK YATIRIM FONU }\end{array}$ & 1.07 .2011 & 2 & 61.613 \\
\hline $\mathrm{ZHN}$ & $\begin{array}{l}\text { ZİRAAT HAYAT VE EMEKLİLIK A.Ş. ALTIN KATILIM } \\
\text { EMEKLİLIK YATIRIM FONU }\end{array}$ & 17.09.2013 & 6 & 94.964 \\
\hline ZHT & $\begin{array}{l}\text { ZİRAAT HAYAT VE EMEKLİLIK A.Ş. KATILIM KATKI } \\
\text { EMEKLİLIKK YATIRIM FONU }\end{array}$ & 30.04 .2013 & 2 & 86.040 \\
\hline
\end{tabular}

Kaynak: http://www.spk.gov.tr/SiteApps/PortfoyDegerleri/YatirimFonlari/E,(Erişim tarihi: 13.06.2019)

Tablo 1'de belirtilen 40 fonun risk değerleri fonun geçmiş performansına göre belirlenmiştir. Risk değeri her zaman değişebilir. Bu risk değerleri fonların en son güncellenmiş KAP'ta yayınlanan fon tanıtım formlarından tespit edilmiştir. Risk seviyeleri fonun geçmiş haftalık getirilerinden elde edilen volatilite (piyasa oynaklığ 1 ) hesaplanması sonucu belirlenmiştir. Bu risk seviyeleri 1-7 arasında değişmektedir. 1-2 arası düşük risk, 3-5 arası orta risk, 6-7 arası yüksek risk seviyesi olarak belirlenmiştir. Risk değeri önemli riskleri kapsamakla birlikte; kredi riski, likidite riski, karşı taraf riski, ihraççı riski, operasyonel risk, türev araç kullanımından kaynaklanan riskler ile piyasalardaki olağanüstü durumlardan kaynaklanabilecek riskleri içermemektedir.

Tablo 2' de gösterilen performans ölçütlerinin hesaplamasında piyasa portföy getirisi $\left(R_{m}\right)$ olarak BIST 100 endeks getirisi ile birlikte analizlere dahil edilen 40 fonun ortalama getirisi de kullanılmıştır. Fon varlık türü oranı en fazla altına dayalı sermaye piyasası araçlarından oluşan fonların Sharpe Oranı, Jensen Alfası, $\mathrm{M}^{2}$ ve Değerleme Oranına göre en iyi performans gösteren fon Katılım Emeklilik ve Hayat A.Ş. Altın Katılım Emeklilik Yatırım Fonu (KEF) iken Treynor ve $\mathrm{T}^{2}$ Oranına göre en iyi performans gösteren fon Axa Hayat ve Emeklilik A.Ş. Altın Katılım Emeklilik Yatırım Fonu (HEA)'dur. BIST 100 endeksine göre fon varlık türü oranı en fazla altına dayalı sermaye piyasası araçlarından oluşan fonların tümünün performans getirileri pozitif olduğundan fon performansları başarılıdır.

Tablo 3'de gösterildiği üzere fon varlık türü oranı en fazla kira sertifikasına dayalı sermaye piyasası araçlarından oluşan fonlardan Sharpe Oran1, Treynor Oranı, Jensen Alfası, $\mathrm{M}^{2}, \mathrm{~T}^{2}$ ve Değerleme Oranına göre en iyi performans getirisi sağlayan fon türü Katılım Emeklilik ve Hayat A.Ş. Katılım Değişken Grup Emeklilik Yatırım Fonu (KEK)'dur. Bu fon 
haricinde fon varlık türü en fazla kira sertifikasına dayalı sermaye araçlarından oluşan fonların hepsinin performans getirileri negatif olduğundan fon performansları başarılı değildir.

\subsubsection{Araştırma Hipotezleri}

Bireysel emeklilik fonları tür yoğunluğu, şirket yönetimi ve risk seviyelerine göre gruplandırılmış olup, belirlenen fon gruplarının performansları arasında farklılık olup olmadığ 1 aşağıda hipotez testleri ile analiz edilmiş̧ir. Hipotez 5 testi ile ise politik bir krizin katılım esasına dayalı emeklilik fonlarının getirileri üzerinde bir etkisinin olup olmadığının testidir.

Hipotez 1: Aynı tür yoğunluğuna sahip katılım esasına dayalı emeklilik fonlarının performansları arasında fark yoktur.

Hipotez 2: Farklı fon şirketlerinin katılım esasına dayalı emeklilik fonlarının performansları arasında fark yoktur.

Hipotez 3: Özel emeklilik fon şirketleri tarafindan yönetilen katılım esasına dayalı emeklilik fonları performansları ile kamu emeklilik fon şirketleri tarafından yönetilen katılım emeklilik fonlarının performansları arasında fark yoktur.

Hipotez 4: Farklı risk grubu içerisinde bulunan katılım esasına dayalı emeklilik fonlarının performansları arasında fark yoktur.

Hipotez 5: Krizlerin katılım esasına dayalı emeklilik yatırım fonlarının getirisi üzerinde etkisi yoktur.

Yapılan analizler sonucunda Hipotez 1, Hipotez 4 ve Hipotez 5 reddedilmiş, Hipotez 2 ve Hipotez 3 kabul edilmiştir. Hipotez 1 ve Hipotez 4 'de ifade edilen fon grupları arasında farklılık bulunurken, Hipotez 2 ve Hipotez 3 'de ifade edilen fon grupları arasında farklılık bulunmamıştır. Hipotez 5 'de ise krizlerin katılım esasına dayalı bireysel emeklilik fonlarının getirileri üzerinde istatiksel olarak anlamlı negatif etkisi olduğu sonucuna ulaşılmıştır. 
Tablo 2. Fon Varlık Türü \%50 ve Üzerinde Altına Dayalı Sermaye Piyasası Araçlarından Oluşan Fonların BIST 100 ve 40

\begin{tabular}{|c|c|c|c|c|c|c|c|c|c|c|c|c|}
\hline \multicolumn{13}{|c|}{ Fon Ortalama Getiri Endeksine Göre Risk Performans Ölçüm Oranları } \\
\hline \multirow[b]{2}{*}{ 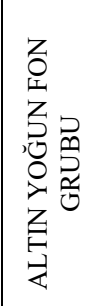 } & \multicolumn{6}{|c|}{ BIST 100} & \multicolumn{6}{|c|}{ ORTALAMA FON } \\
\hline & 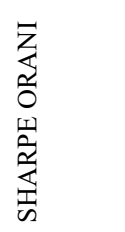 & 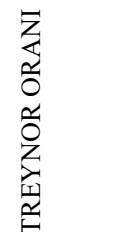 & 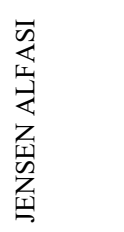 & $\begin{array}{l}\bar{z} \\
\text { I } \\
0 \\
\text { z }\end{array}$ & $\begin{array}{l}\bar{z} \\
\text { Z } \\
\text { Oे } \\
\text { r. }\end{array}$ & 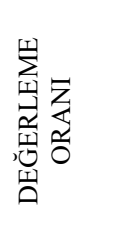 & 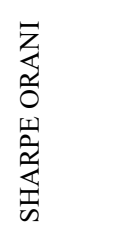 & 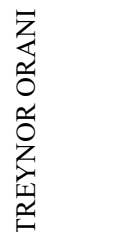 & 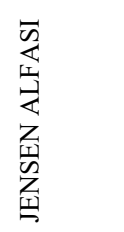 & 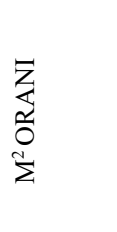 & 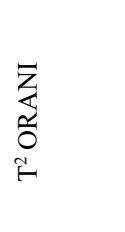 & 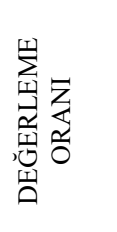 \\
\hline AEA & 0,02450 & 0,00789 & 0,00028 & 0,00057 & 0,00815 & 0,02532 & 0,02450 & 0,00010 & 0,00031 & 0,00009 & 0,00011 & 0,05266 \\
\hline AEL & 0,02569 & 0,00860 & 0,00030 & 0,00059 & 0,00886 & 0,02648 & 0,02569 & 0,00010 & 0,00033 & 0,00010 & 0,00011 & 0,05362 \\
\hline HEA & 0,02484 & 0,00888 & 0,00027 & 0,00058 & 0,00914 & 0,02558 & 0,02484 & 0,00010 & 0,00030 & 0,00010 & 0,00011 & 0,05386 \\
\hline AGA & 0,02526 & 0,00839 & 0,00029 & 0,00058 & 0,00865 & 0,02606 & 0,02526 & 0,00010 & 0,00033 & 0,00010 & 0,00011 & 0,05319 \\
\hline BNA & 0,02428 & 0,00820 & $\begin{array}{c}0,00029 \\
\end{array}$ & 0,00057 & 0,00846 & 0,02506 & 0,02428 & 0,00010 & 0,00032 & 0,00009 & 0,00011 & 0,05160 \\
\hline GHA & 0,02499 & 0,00845 & 0,00029 & 0,00058 & 0,00871 & 0,02578 & 0,02499 & 0,00010 & 0,00032 & 0,00010 & 0,00011 & 0,05303 \\
\hline KEF & 0,02614 & 0,00887 & 0,00030 & 0,00059 & 0,00913 & 0,02692 & 0,02614 & 0,00010 & 0,00033 & 0,00010 & 0,00012 & 0,05527 \\
\hline $\mathrm{VGA}$ & 0,02553 & 0,00845 & 0,00029 & 0,00059 & 0,00871 & 0,02633 & 0,02553 & 0,00010 & 0,00032 & 0,00010 & 0,00011 & 0,05623 \\
\hline ZHN & 0,02492 & 0,00841 & 0,00029 & 0,00058 & 0,00867 & 0,02571 & 0,02492 & 0,00010 & 0,00032 & 0,00010 & 0,00011 & 0,05260 \\
\hline
\end{tabular}


Tablo 3. Fon Varlık Türü \%50 ve Üzerinde Kira Sertifikasına Dayalı Sermaye Piyasası Araçlarından Oluşan Fonların BIST 100 ve 40 Fon Ortalama Getiri Endeksine Göre Risk Performans Ölçüm Oranları

\begin{tabular}{|c|c|c|c|c|c|c|c|c|c|c|c|c|}
\hline \multirow{2}{*}{ 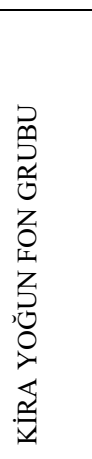 } & \multicolumn{6}{|c|}{ BIST 100} & \multicolumn{6}{|c|}{ ORTALAMA FON } \\
\hline & 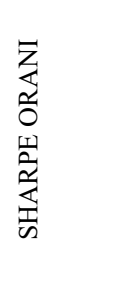 & 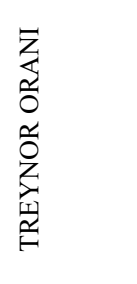 & 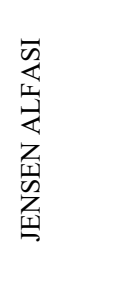 & $\begin{array}{l}\bar{z} \\
\approx \\
0 \\
\Sigma \\
\Sigma\end{array}$ & 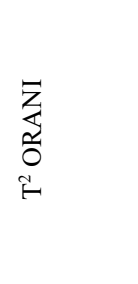 & 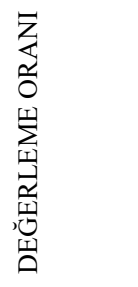 & 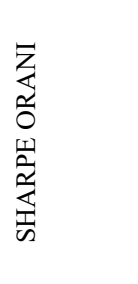 & 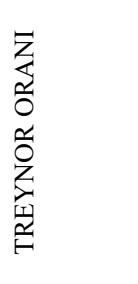 & 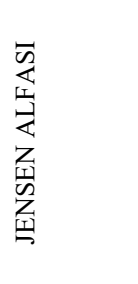 & 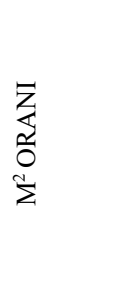 & 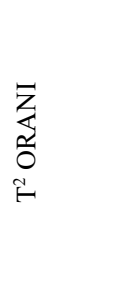 & 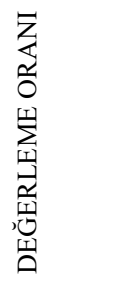 \\
\hline AER & $-0,08872$ & $-0,13382$ & $-0,00010$ & $-0,00087$ & $-0,13356$ & $-0,08855$ & $-0,08872$ & $-0,00208$ & $-0,00010$ & $-0,00028$ & $-0,00206$ & $\begin{array}{l}-0,08902 \\
\end{array}$ \\
\hline AGE & $-0,06393$ & $-0,01916$ & $-0,00015$ & $-0,00055$ & $-0,01890$ & $-0,06312$ & $-0,06393$ & $-0,00076$ & $-0,00015$ & $-0,00020$ & $-0,00075$ & $-0,06534$ \\
\hline HEE & $-0,03414$ & $-0,01236$ & $-0,00009$ & $-0,00017$ & $-0,01210$ & $-0,03344$ & $-0,03414$ & $-0,00038$ & $-0,00009$ & $-0,00010$ & $-0,00037$ & $-0,03445$ \\
\hline HER & $-0,04977$ & $-0,03675$ & $-0,00005$ & $-0,00037$ & $-0,03649$ & $-0,04942$ & $-0,04977$ & $-0,00109$ & $-0,00005$ & $-0,00015$ & $-0,00108$ & $-0,04972$ \\
\hline AGB & $-0,03048$ & $-0,02795$ & $-0,00010$ & $-0,00013$ & $\begin{array}{l}-0,02769 \\
\end{array}$ & $-0,03020$ & $-0,03048$ & $-0,00023$ & $-0,00009$ & $-0,00009$ & $-0,00022$ & $-0,03186$ \\
\hline AGD & $-0,16338$ & $-0,10517$ & $-0,00014$ & $-0,00182$ & $-0,10491$ & $-0,16300$ & $-0,16338$ & $-0,00507$ & $-0,00014$ & $-0,00052$ & $-0,00506$ & $-0,16386$ \\
\hline AGG & $-0,03188$ & $-0,03267$ & $-0,00008$ & $-0,00015$ & $-0,03240$ & $-0,03162$ & $-0,03188$ & $-0,00022$ & $-0,00007$ & $-0,00009$ & $-0,00020$ & $-0,03416$ \\
\hline AGH & $-0,01208$ & $-0,01921$ & $-0,00011$ & 0,00011 & $-0,01895$ & $-0,01192$ & $-0,01208$ & $-0,00014$ & $-0,00010$ & $-0,00003$ & $-0,00013$ & $-0,01139$ \\
\hline AGM & $-0,01575$ & $-0,01305$ & $-0,00005$ & 0,00006 & $-0,01279$ & $-0,01544$ & $-0,01575$ & $-0,00006$ & $-0,00004$ & $-0,00004$ & $-0,00005$ & $-0,02132$ \\
\hline AGT & $-0,07423$ & $-0,03159$ & $-0,00019$ & $-0,00069$ & $-0,03133$ & $-0,07366$ & $-0,07423$ & $-0,00573$ & $-0,00019$ & $-0,00023$ & $-0,00571$ & $-0,07413$ \\
\hline GEA & $-0,04778$ & $-0,01728$ & $-0,00013$ & $-0,00035$ & $-0,01702$ & $-0,04709$ & $-0,04778$ & $-0,00037$ & $-0,00013$ & $-0,00014$ & $-0,00036$ & $-0,05077$ \\
\hline GES & $-0,16631$ & 0,19437 & $-0,00016$ & $-0,00186$ & 0,19463 & $-0,16654$ & $-0,16631$ & $-0,01120$ & $-0,00016$ & $-0,00053$ & $-0,01119$ & $-0,16630$ \\
\hline GHL & $-0,07590$ & $-0,08667$ & $-0,00008$ & $-0,00071$ & $-0,08641$ & $-0,07567$ & $-0,07590$ & $-0,00158$ & $-0,00008$ & $-0,00024$ & $-0,00156$ & $-0,07621$ \\
\hline HHA & $-0,08113$ & $-0,02990$ & $-0,00009$ & $-0,00077$ & $-0,02964$ & $-0,08047$ & $-0,08113$ & $-0,00121$ & $-0,00009$ & $-0,00025$ & $-0,00120$ & $-0,08223$ \\
\hline HHD & $-0,19869$ & $-0,13423$ & $-0,00016$ & $-0,00227$ & $-0,13397$ & $-0,19833$ & $-0,19869$ & $-0,01094$ & $-0,00016$ & $-0,00064$ & $-0,01092$ & $-0,19879$ \\
\hline HHM & $-0,00842$ & $-0,00659$ & $-0,00008$ & 0,00015 & $-0,00633$ & $-0,00809$ & $-0,00842$ & $-0,00010$ & $-0,00007$ & $-0,00001$ & $-0,00008$ & $-0,00756$ \\
\hline HHN & $-0,03723$ & $-0,02982$ & $-0,00013$ & $-0,00021$ & $-0,02955$ & $-0,03691$ & $-0,03723$ & $-0,00035$ & $-0,00012$ & $-0,00011$ & $-0,00033$ & $-0,03825$ \\
\hline
\end{tabular}




\section{Muhasebe ve Finansman Dergisi - Nisan/2020}

(86): 153-184

\begin{tabular}{|c|c|c|c|c|c|c|c|c|c|c|c|c|}
\hline KEA & $-0,10047$ & $-0,29933$ & $-0,00010$ & $-0,00102$ & $-0,29907$ & $-0,10038$ & $-0,10047$ & $-0,00457$ & $-0,00010$ & $-0,00032$ & $-0,00456$ & $-0,10043$ \\
\hline KEB & $-0,11632$ & 0,14258 & $-0,00011$ & $-0,00122$ & 0,14284 & $-0,11653$ & $-0,11632$ & $-0,00378$ & $-0,00011$ & $-0,00037$ & $-0,00377$ & $-0,11649$ \\
\hline KEG & $-0,02553$ & $-0,01145$ & $-0,00006$ & $-0,00007$ & $-0,01119$ & $-0,02496$ & $-0,02553$ & $-0,00016$ & $-0,00006$ & $-0,00007$ & $-0,00015$ & $-0,02723$ \\
\hline KEH & $-0,01057$ & $-0,02545$ & $-0,00010$ & 0,00013 & $-0,02519$ & $-0,01046$ & $-0,01057$ & $-0,00013$ & $-0,00009$ & $-0,00002$ & $-0,00011$ & $-0,00982$ \\
\hline KEK & 0,00682 & 0,00235 & 0,00002 & 0,00035 & 0,00261 & 0,00758 & 0,00682 & 0,00004 & 0,00002 & 0,00004 & 0,00005 & 0,01148 \\
\hline MHA & $-0,13957$ & $-0,14316$ & $-0,00017$ & $-0,00152$ & $-0,14289$ & $-0,13933$ & $-0,13957$ & $-0,00318$ & $-0,00017$ & $-0,00045$ & $-0,00317$ & $-0,14044$ \\
\hline MHS & $-0,06243$ & $-0,03482$ & $-0,00016$ & $-0,00054$ & $-0,03456$ & $-0,06198$ & $-0,06243$ & $-0,00073$ & $-0,00016$ & $-0,00019$ & $-0,00072$ & $-0,06382$ \\
\hline VEA & $-0,08906$ & $-0,01998$ & $-0,00015$ & $-0,00088$ & $-0,01972$ & $-0,08804$ & $-0,08906$ & $-0,00329$ & $-0,00016$ & $-0,00028$ & $-0,00327$ & $-0,08905$ \\
\hline VEB & $-0,04784$ & $-0,03134$ & $-0,00015$ & $-0,00035$ & $-0,03108$ & $-0,04745$ & $-0,04784$ & $-0,00051$ & $-0,00015$ & $-0,00014$ & $-0,00049$ & $-0,04898$ \\
\hline VER & $-0,07453$ & $-0,09539$ & $-0,00009$ & $-0,00069$ & $-0,09513$ & $-0,07433$ & $-0,07453$ & $-0,00115$ & $-0,00009$ & $-0,00023$ & $-0,00113$ & $-0,07539$ \\
\hline VEY & $-0,03310$ & $-0,01975$ & $-0,00011$ & $-0,00016$ & $-0,01949$ & $-0,03267$ & $-0,03310$ & $-0,00036$ & $-0,00011$ & $-0,00010$ & $-0,00034$ & $-0,03344$ \\
\hline VGB & $-0,10457$ & $-0,06972$ & $-0,00012$ & $-0,00107$ & $-0,06946$ & $-0,10420$ & $-0,10457$ & $-0,00141$ & $-0,00012$ & $-0,00033$ & $-0,00140$ & $-0,10679$ \\
\hline ZHA & $-0,14575$ & 0,21313 & $-0,00012$ & $-0,00160$ & 0,21339 & $-0,14592$ & $-0,14575$ & $-0,00352$ & $-0,00012$ & $-0,00047$ & $-0,00350$ & $-0,14655$ \\
\hline ZHT & $-0,06115$ & 0,20919 & $-0,00006$ & $-0,00052$ & 0,20945 & $-0,06122$ & $-0,06115$ & $-0,00154$ & $-0,00006$ & $-0,00019$ & $-0,00153$ & $-0,06113$ \\
\hline
\end{tabular}


Tablo 4. Altın ve Kira Sertifikası Yoğunluğu Fazla Olan Fonların BIST 100 Endeksine Göre İstatiksel Analizi

\begin{tabular}{|c|c|c|c|c|c|c|}
\hline \multirow{2}{*}{$\begin{array}{l}\text { Altın ve Kira Fon } \\
\text { Türüne Göre } \\
\text { İstatistiksel } \\
\text { Analiz/BIST } 100\end{array}$} & \multicolumn{2}{|c|}{ Normallik Testi } & \multicolumn{2}{|c|}{ t Testi } & \multicolumn{2}{|c|}{ Mann Whitney U Testi } \\
\hline & $\begin{array}{c}\text { İstatistik } \\
\text { Değeri }\end{array}$ & $\begin{array}{l}\text { Olasıllık } \\
\text { Değeri } \\
\text { (Sign) }\end{array}$ & $\begin{array}{c}\text { İstatistik } \\
\text { Değeri }\end{array}$ & $\begin{array}{l}\text { Olasılık } \\
\text { Değeri } \\
\text { (Sign) }\end{array}$ & $\begin{array}{c}\text { İstatistik } \\
\text { Değeri }\end{array}$ & $\begin{array}{c}\text { Olasilık } \\
\text { Değeri } \\
\text { (Sign) }\end{array}$ \\
\hline Sharpe Oran1 & 0,111 & 0,200 & 5,497 & $0,000^{* * *}$ & & \\
\hline Treynor Oran 1 & 0,292 & 0,000 & & & 36,000 & $0,001 * * *$ \\
\hline Jensen Alfa & 0,314 & 0,000 & & & 0,000 & $0,000^{* * *}$ \\
\hline $\mathrm{M}^{2}$ & 0,111 & 0,200 & 5,497 & $0,000^{* *}$ & & \\
\hline $\mathrm{T}^{2}$ & 0,292 & 0,000 & & & 36,000 & $0,001 * * *$ \\
\hline Değerleme Oranı & 0,111 & 0,200 & 5,513 & $0,000 * *$ & & \\
\hline
\end{tabular}

Altın ve kira sertifikası yoğunluğuna göre fonları grupladığımızda hesaplanmış olan her bir performans ölçütü için grupların performanslarının istatistiksel olarak birbirinden farklı olup olmadıkları analiz edilmiş ve sonuçlar Tablo 4'de gösterilmiştir. Altın ve kira türü fon gruplarının performansları arasında farklılık olup olmadığının test edilmesi için önce fon serisinin normallik varsayımı sağlayıp sağlamadığının tespit edilmesi gerekmektedir. Verilerin normal dağılıma uygun olup olmadığı Kolmogrov-Smimov testi kullanılarak analiz edilmiştir. Altın ve kira sertifikası fon gruplarının Sharpe Oranı, $\mathrm{M}^{2}$ ve Değerleme Oranına göre hesaplanmış performansları normal dağılmaktadır. Normal dağılıma sahip fon gruplarımızın performans ölçütleri arasında anlamlı farklılık olup olmadığı fon grubumuzun iki olması (altın ve kira) sebebiyle t testi ile analizi edilmiştir. Altın ve kira sertifikası fon gruplarının Treynor Oranı, Jensen Alfası ve $\mathrm{T}^{2}$ Oranına göre hesaplanmış performansları normal dağılmamaktadır. Normal dağılıma sahip olmayan seriler arasında anlamlı bir farklılık olup olmadığı fon grubumuzun iki olması (altın ve kira) sebebiyle Mann Whitney $U$ testi ile analiz edilmiştir. Analizlerde kullanılan t testi ve Mann White $\mathrm{U}$ testi olasılık değerleri 0,05 ten küçük olduğundan dolayı hipotezimiz reddedilmiştir. Altın varlık türü yoğunluğu fazla olan fonların performansları ile kira sertifikası türü yoğunluğu fazla fonların performansları arasında anlamlı bir farklılık bulunmaktadır. Benzer şekilde 40 fonun ortalama getirisi endeksine göre hesaplanmış altın varlık türü yoğunluğu fazla olan fonların performansları ile kira sertifikası türü yoğunluğu fazla fonların performansları arasında anlamlı bir farklılık bulunup bulunmadığı analiz edilmiş, fark olmadığı tespit edilmiş ve analiz sonuçları Tablo 5 te gösterilmiştir. Tablo 4 ve Tablo 5 te yer alan sonuçlar bir numaralı hipotezin reddedildiğini göstermektedir. 
Tablo 5. Altın ve Kira Sertifikası Yoğunluğu Fazla Olan Fonların 40 Fonun Ortalama Getiri Endeksine Göre İstatiksel Analizi

\begin{tabular}{|c|c|c|c|c|c|c|}
\hline \multirow{2}{*}{$\begin{array}{c}\text { Altın ve Kira Fon } \\
\text { Türüne Göre } \\
\text { İstatistiksel } \\
\text { Analiz/ORT_FON }\end{array}$} & \multicolumn{2}{|c|}{ Normallik Testi } & \multicolumn{2}{|c|}{$\mathrm{t}$ Testi } & \multicolumn{2}{|c|}{ Mann Whitney U Testi } \\
\hline & $\begin{array}{c}\text { İstatistik } \\
\text { değeri }\end{array}$ & $\begin{array}{l}\text { Olasılık } \\
\text { değeri } \\
\text { (sign) }\end{array}$ & $\begin{array}{c}\text { İstatistik } \\
\text { değeri }\end{array}$ & $\begin{array}{l}\text { Olasılık } \\
\text { Değeri } \\
\text { (Sign) }\end{array}$ & $\begin{array}{c}\text { İstatistik } \\
\text { Değeri }\end{array}$ & $\begin{array}{l}\text { Olasılık } \\
\text { Değeri } \\
\text { (Sign) }\end{array}$ \\
\hline Sharpe Oranı & 0,111 & 0,200 & 5,497 & $0,000^{* * *}$ & & \\
\hline Treynor Oranı & 0,261 & 0,000 & & & 0,000 & $0,000 * * *$ \\
\hline Jensen Alfa & 0,316 & 0,000 & & & 0,000 & $0,000 * * *$ \\
\hline $\mathrm{M}^{2}$ & 0,111 & 0,200 & 5,495 & $0,000^{* * *}$ & & \\
\hline $\mathrm{T}^{2}$ & 0,261 & 0,000 & & & 0,000 & $0,000 * * *$ \\
\hline Değerleme Oranı & 0,138 & 0,053 & 7,158 & $0,000 * * *$ & & \\
\hline
\end{tabular}

Not: *\%10 seviyesinde, **\% 5 seviyesinde, $* * * \% 1$ seviyesinde istatistiksel olarak anlaml 1

Farklı fon şirketlerinin fon performansları arasında anlamlı bir farklılık olup olmadığı Tablo 6'da ve Tablo 7`de gösterilmiştir. Analizlerde yer alan fon grupları ikiden fazla olduğu için normal dağılıma sahip performans ölçütleri için Anova testi (Tek Yönlü Varyans Analizi), normal dağılıma sahip olmayan performans ölçütleri için Kruskal Wallistesti kullanılarak analizler yapılmıştır. Test istatistiklerindeki olasılık değeri 0,05 ten büyük olduğundan dolayı hipotezimiz kabul edilmiştir. Farklı fon şirketlerinin fon performansları arasında anlamlı bir farklılık yoktur. Tablo 6 ve Tablo 7 'de yer alan sonuçlar iki numarala hipotezin kabul edildiğini göstermektedir.

Analizi

Tablo 6. Fon Şirketlerinin Fonlarının BIST 100 Endeksine Göre İstatiksel

\begin{tabular}{|c|c|c|c|c|c|c|}
\hline \multirow[b]{2}{*}{$\begin{array}{l}\text { Fon Şirketlerine } \\
\text { Göre İstatistiksel } \\
\text { Analiz/BIST } 100\end{array}$} & \multicolumn{2}{|c|}{ Normallik Testi } & \multicolumn{2}{|c|}{ Anova Testi } & \multicolumn{2}{|c|}{ Kruskal Wallis Testi } \\
\hline & $\begin{array}{c}\text { İstatistik } \\
\text { Değeri }\end{array}$ & $\begin{array}{c}\text { Olasılık } \\
\text { Değeri } \\
\text { (Sign) }\end{array}$ & $\begin{array}{c}\text { İstatistik } \\
\text { Değeri }\end{array}$ & $\begin{array}{l}\text { Olasılık } \\
\text { Değeri } \\
\text { (Sign) }\end{array}$ & $\begin{array}{c}\text { İstatistik } \\
\text { Değeri }\end{array}$ & $\begin{array}{c}\text { Olasılık } \\
\text { Değeri } \\
\text { (Sign) }\end{array}$ \\
\hline Sharpe Oran1 & 0,111 & 0,200 & 0,644 & 0,764 & & \\
\hline Treynor Oranı & 0,292 & 0,000 & & & 14,636 & 0,146 \\
\hline Jensen Alfa & 0,321 & 0,000 & & & 13,074 & 0,220 \\
\hline $\mathrm{M}^{2}$ & 0,111 & 0,200 & 0,647 & 0,762 & & \\
\hline $\mathrm{T}^{2}$ & 0,292 & 0,000 & & & 14,636 & 0,146 \\
\hline Değerleme Oranı & 0,111 & 0,200 & 0,644 & 0,764 & & \\
\hline
\end{tabular}

Not: *\%10 seviyesinde, **\% 5 seviyesinde, $* * * \% 1$ seviyesinde istatistiksel olarak anlaml 
Tablo 7. Fon Şirketlerinin Fonlarının 40 Fonun Ortalama Getiri Endeksine Göre İstatiksel Analizi

\begin{tabular}{|c|c|c|c|c|c|c|}
\hline \multirow[b]{2}{*}{$\begin{array}{l}\text { Fon şirketlerine } \\
\text { göre istatistiksel } \\
\text { analiz/ORT_FON }\end{array}$} & \multicolumn{2}{|c|}{ Normallik Testi } & \multicolumn{2}{|c|}{ Anova Testi } & \multicolumn{2}{|c|}{ Kruskal Wallis Testi } \\
\hline & $\begin{array}{c}\text { İstatistik } \\
\text { Değeri }\end{array}$ & $\begin{array}{l}\text { Olasıllk } \\
\text { Değeri } \\
\text { (Sign) }\end{array}$ & $\begin{array}{c}\text { İstatistik } \\
\text { Değeri }\end{array}$ & $\begin{array}{l}\text { Olasılik } \\
\text { Değeri } \\
\text { (Sign) }\end{array}$ & $\begin{array}{c}\text { İstatistik } \\
\text { Değeri }\end{array}$ & $\begin{array}{l}\text { Olasılık } \\
\text { Değeri } \\
\text { (Sign) }\end{array}$ \\
\hline Sharpe Oranı & 0,111 & 0,200 & 0,644 & 0,764 & & \\
\hline Treynor Oranı & 0,356 & 0,000 & & & 5,345 & 0,867 \\
\hline Jensen Alfa & 0,240 & 0,000 & & & 11,939 & 0,289 \\
\hline $\mathrm{M}^{2}$ & 0,102 & 0,200 & 0,812 & 0,619 & & \\
\hline $\mathrm{T}^{2}$ & 0,266 & 0,000 & & & 7,144 & 0,712 \\
\hline Değerleme Oranı & 0,114 & 0,200 & 0,788 & 0,640 & & \\
\hline
\end{tabular}

Not: *\%10 seviyesinde, **\% 5 seviyesinde, $* * * \% 1$ seviyesinde istatistiksel olarak anlaml

Kamu tarafından yönetilen katılım esasına dayalı bireysel emeklilik fonlarının performansları ile özel şirketler tarafından yönetilen fonların performansları arasında farklılık olup olmadığ $t$ testi ve Mann Whitney U testi ile analiz edilmiş ve sonuçlar Tablo 8 ve Tablo 9'da gösterilmiştir. Analizlerde kullanılan $t$ testi ve Mann White $U$ testi olasılık değerleri 0,05 ten büyük olduğundan dolayı hipotezimiz kabul edilmiştir. Kamu tarafindan yönetilen katılım esasına dayalı bireysel emeklilik fonlarının performansları ile özel şirketler tarafından yönetilen katılım esasına dayalı bireysel emeklilik fonlarının performansları arasında anlamlı bir farklılık yoktur. Tablo 8 ve Tablo 9`da yer alan sonuçlar üç numaralı hipotezin kabul edildiğini göstermektedir.

Tablo 8. Kamu Şirketleri ve Özel Şirketler Tarafından Yönetilen Fonlarının BIST 100 Endeksine Göre İstatiksel Analizi

\begin{tabular}{|c|c|c|c|c|c|c|}
\hline \multirow{2}{*}{$\begin{array}{c}\text { Kamu ve Özel } \\
\text { Şirketlere Göre } \\
\text { İstatistiksel } \\
\text { Analiz/BIST } 100\end{array}$} & \multicolumn{2}{|c|}{ Normallik Testi } & \multicolumn{2}{|c|}{ t Testi } & \multicolumn{2}{|c|}{ Mann Whitney U Testi } \\
\hline & $\begin{array}{c}\text { İstatistik } \\
\text { Değeri }\end{array}$ & $\begin{array}{l}\text { Olasılık } \\
\text { Değeri } \\
\text { (Sign) }\end{array}$ & $\begin{array}{c}\text { İstatistik } \\
\text { Değeri }\end{array}$ & $\begin{array}{l}\text { Olasılık } \\
\text { Değeri } \\
\text { (Sign) }\end{array}$ & $\begin{array}{c}\text { İstatistik } \\
\text { Değeri }\end{array}$ & $\begin{array}{l}\text { Olasılık } \\
\text { Değeri } \\
\text { (Sign) }\end{array}$ \\
\hline Sharpe Oranı & 0,111 & 0,200 & $-0,802$ & 0,428 & & \\
\hline Treynor Oranı & 0,292 & 0,000 & & & 171,500 & 0,441 \\
\hline Jensen Alfa & 0,321 & 0,000 & & & 163,000 & 0,316 \\
\hline $\mathrm{M}^{2}$ & 0,111 & 0,200 & $-0,803$ & 0,427 & & \\
\hline $\mathrm{T}^{2}$ & 0,292 & 0,000 & & & 171,500 & 0,441 \\
\hline Değerleme Oranı & 0,111 & 0,200 & $-0,803$ & 0,427 & & \\
\hline
\end{tabular}

Not: *\%10 seviyesinde, $* * \% 5$ seviyesinde, $* * * \% 1$ seviyesinde istatistiksel olarak anlaml 1 
Tablo 9. Kamu Şirketleri ve Özel Şirketler Tarafından Yönetilen Fonlarının 40 Fonun Ortalamasına Göre İstatiksel Analizi

\begin{tabular}{|c|c|c|c|c|c|c|}
\hline \multirow{2}{*}{$\begin{array}{c}\text { Kamu ve Özel } \\
\text { Şirketlere Göre } \\
\text { İstatistiksel } \\
\text { Analiz/ORT_FON }\end{array}$} & \multicolumn{2}{|c|}{ Normallik Testi } & \multicolumn{2}{|c|}{$\mathrm{t}$ Testi } & \multicolumn{2}{|c|}{ Mann Whitney U Testi } \\
\hline & $\begin{array}{c}\text { İstatistik } \\
\text { Değeri }\end{array}$ & $\begin{array}{l}\text { Olasılık } \\
\text { Değeri } \\
\text { (Sign) }\end{array}$ & $\begin{array}{c}\text { İstatistik } \\
\text { Değeri }\end{array}$ & $\begin{array}{l}\text { Olasılık } \\
\text { Değeri } \\
\text { (Sign) }\end{array}$ & $\begin{array}{c}\text { İstatistik } \\
\text { Değeri }\end{array}$ & $\begin{array}{l}\text { Olasılık } \\
\text { Değeri } \\
\text { (Sign) }\end{array}$ \\
\hline Sharpe Oranı & 0,111 & 0,200 & $-0,802$ & 0,428 & & \\
\hline Treynor Oranı & 0,261 & 0,000 & & & 177,000 & 0,534 \\
\hline Jensen Alfa & 0,316 & 0,000 & & & 166,000 & 0,358 \\
\hline $\mathrm{M}^{2}$ & 0,111 & 0,200 & $-0,802$ & 0,428 & & \\
\hline $\mathrm{T}^{2}$ & 0,261 & 0,000 & & & 177,000 & 0,534 \\
\hline Değerleme Oranı & 0,138 & 0,200 & $-0,917$ & 0,365 & & \\
\hline
\end{tabular}

Not: *\%10 seviyesinde, **\% 5 seviyesinde, $* * * \% 1$ seviyesinde istatistiksel olarak anlamlı

Farklı risk grubu içerisinde bulunan katılım esasına dayalı emeklilik fonlarının performansları arasında fark olup olmadığı Anova testi ve Kruskal Wallis Testi ile test edilmiş ve analiz sonuçları Tablo 10 ve Tablo 11'de listelenmiştir. Analizlerde kullanılan Anova testi ve Kruskal Wallis Testi olasılık değerleri 0,05 ten küçük olduğundan dolayı hipotezimiz reddedilmiştir. Risk seviyesine göre belirlenmiş katılım esasına dayalı bireysel emeklilik fonlarının performansları arasında anlamlı farklılık vardır. Tablo 10 ve Tablo 11 'de yer alan sonuçlar dört numaralı hipotezin reddedildiğini göstermektedir.

Tablo 10. Risk Seviyesine Göre Belirlenen Fonlarının BIST 100 Endeksine Göre İstatiksel Analizi

\begin{tabular}{|c|c|c|c|c|c|c|}
\hline \multirow{2}{*}{$\begin{array}{c}\text { Risk seviyelerine } \\
\text { göre istatistiksel } \\
\text { analiz/BIST 100 }\end{array}$} & \multicolumn{2}{|c|}{ Normallik Testi } & \multicolumn{2}{|c|}{ Anova Testi } & \multicolumn{2}{c|}{ Kruskal Wallis Testi } \\
\cline { 2 - 7 } & $\begin{array}{c}\text { Istatistik } \\
\text { Değeri }\end{array}$ & $\begin{array}{c}\text { Olasılık } \\
\text { Değeri } \\
\text { (Sign) }\end{array}$ & $\begin{array}{c}\text { Istatistik } \\
\text { Değeri }\end{array}$ & $\begin{array}{c}\text { Olasılık } \\
\text { Değeri } \\
\text { (Sign) }\end{array}$ & $\begin{array}{c}\text { İstatistik } \\
\text { Değeri }\end{array}$ & $\begin{array}{c}\text { Olasılık } \\
\text { Değeri } \\
\text { (Sign) }\end{array}$ \\
\hline $\begin{array}{c}\text { Sharpe O } \\
\text { ran1 }\end{array}$ & 0,111 & 0,200 & 20,504 & $0,000^{* * *}$ & & \\
\hline Treynor Oranı & 0,292 & 0,000 & & & 9,158 & $0,057^{*}$ \\
\hline Jensen Alfa & 0,314 & 0,000 & & & 16,256 & $0,003^{* * *}$ \\
\hline $\mathrm{M}^{2}$ & 0,111 & 0,200 & 20,504 & $0,000^{* * *}$ & & $0,057^{*}$ \\
\hline $\mathrm{T}^{2}$ & 0,292 & 0,000 & & & 9,158 & \\
\hline Değerleme Oranı & 0,111 & 0,200 & 20,542 & $0,000^{* * *}$ & & \\
\hline
\end{tabular}

Not: $* \% 10$ seviyesinde, $* * \% 5$ seviyesinde, $* * * \% 1$ seviyesinde istatistiksel olarak anlaml 
Tablo 11. Risk Seviyesine Göre Belirlenen Fonlarının 40 Fonun Ortalama Getiri Endeksine Göre İstatiksel Analizi

\begin{tabular}{|c|c|c|c|c|c|c|}
\hline \multirow[b]{2}{*}{$\begin{array}{l}\text { Risk seviyelerine } \\
\text { göre istatistiksel } \\
\text { analiz/ORT_FON }\end{array}$} & \multicolumn{2}{|c|}{ Normallik Testi } & \multicolumn{2}{|c|}{ Anova Testi } & \multicolumn{2}{|c|}{ Kruskal Wallis Testi } \\
\hline & $\begin{array}{c}\text { İstatistik } \\
\text { Değeri }\end{array}$ & $\begin{array}{l}\text { Olasılık } \\
\text { Değeri } \\
\text { (Sign) }\end{array}$ & $\begin{array}{c}\text { İstatistik } \\
\text { Değeri }\end{array}$ & $\begin{array}{l}\text { Olasılık } \\
\text { Değeri } \\
\text { (Sign) }\end{array}$ & $\begin{array}{c}\text { İstatistik } \\
\text { Değeri }\end{array}$ & $\begin{array}{l}\text { Olasılık } \\
\text { Değeri } \\
\text { (Sign) }\end{array}$ \\
\hline Sharpe Oranı & 0,111 & 0,200 & 20,504 & $0,000 * * *$ & & \\
\hline Treynor Oranı & 0,261 & 0,000 & & & 28,989 & $0,000 * * *$ \\
\hline Jensen Alfa & 0,316 & 0,000 & & & 18,098 & $0,001 * * *$ \\
\hline $\mathrm{M}^{2}$ & 0,111 & 0,200 & 20,504 & $0,000 * * *$ & & \\
\hline $\mathrm{T}^{2}$ & 0,261 & 0,000 & & & 28,989 & $0,000 * * *$ \\
\hline Değerleme Oranı & 0,138 & 0,053 & 24,858 & $0,000 * * *$ & & \\
\hline
\end{tabular}

Not: *\%10 seviyesinde, $* * \% 5$ seviyesinde, $* * * \% 1$ seviyesinde istatistiksel olarak anlaml

\subsubsection{Krizin Katılım Esasına Dayalı Emeklilik Yatırım Fonlarının Getirileri Üzerindeki Etkisi}

Katılım esasına dayalı bireysel emeklilik fonlarının performanslarını incelediğimiz dönem içerisinde 15 Temmuz 2016 tarihinde bir politik kriz yaşanmıştır. Politik krizin katılım esasına dayalı emeklilik yatırım fonlarının getirisi üzerindeki etkisi, 1985 yılında Brown ve Warner'in çalışmasında kullandığı olay etüdü yöntemi ile analiz edilmiş ve sonuçlar Tablo 12 'de gösterilmiştir. Emeklilik yatırım fonlarında pay alım talimatları; ileri fiyat uygulanan fonlarda talimatın verilmesini takip eden ilk iş gününde $(T+1)$, geri fiyat uygulanan fonlarda ise talimatın verildiği iş günü $(\mathrm{T})$ verilmektedir ${ }^{1}$. Bundan dolayı anormal getiriler olayın gerçekleştiği günü takip eden 19.07.2016 tarihi baz alınarak değerlendirilmiştir.

Tablo 12. Düzeltilmiş Ortalama Getiri Yöntemi ile Hesaplanan 40 Fonun Anormal Getirileri (19/07/2016 Tarihli Getiriler)

\begin{tabular}{|c|c|c|c|c|}
\hline Fon Kodu & Fonun Halka Arz Tarihi & $\begin{array}{c}\text { Risk Oranı } \\
(1-7 \text { Arasında) }\end{array}$ & $\begin{array}{c}\text { AR (Anormal Getiri) 19.07.2016 } \\
\text { T+2 Dönemi }\end{array}$ & t İstatistiği \\
\hline AEA & 30.04 .2013 & 6 & 0,0182 & 1,6254 \\
\hline AER & 30.04 .2013 & 2 & $-0,0034$ & $-4,1000^{* *}$ \\
\hline AGE & 30.11 .2010 & 2 & $-0,0187$ & $-5,3757^{* *}$ \\
\hline AEL & 7.08 .2013 & 5 & 0,0185 & 1,5715 \\
\hline
\end{tabular}

${ }^{1}$ http://spk.gov.tr/Sayfa/Dosya/1205, Erişim: 13.06.2019. 


\begin{tabular}{|c|c|c|c|c|}
\hline HEA & 1.10 .2013 & 6 & 0,0154 & 1,3922 \\
\hline HEE & 1.10 .2013 & 4 & $-0,0187$ & $-5,3705^{* *}$ \\
\hline HER & 1.10 .2013 & 3 & $-0,0033$ & $-3,7576^{* *}$ \\
\hline AGA & 7.05 .2013 & 6 & 0,0185 & 1,5673 \\
\hline AGB & 5.06 .2012 & 5 & $-0,0243$ & $-7,3247 * *$ \\
\hline AGD & 7.05 .2013 & 2 & $-0,0005$ & $-0,8627$ \\
\hline AGG & 12.06 .2012 & 4 & $-0,0167$ & $-6,8150 * *$ \\
\hline $\mathrm{AGH}$ & 28.05 .2012 & 6 & $-0,0635$ & $-7,5153 * *$ \\
\hline AGM & 21.05 .2012 & 2 & $-0,0021$ & $-1,8025^{* *}$ \\
\hline AGT & 2.05 .2013 & 2 & $-0,0003$ & $-0,5024$ \\
\hline BNA & 30.04 .2013 & 6 & 0,0185 & 1,5668 \\
\hline GEA & 6.05 .2009 & 4 & $-0,0186$ & $-5,5986^{* *}$ \\
\hline GES & 26.06 .2013 & 2 & $-0,0005$ & $-0,7901$ \\
\hline GHA & 26.06 .2013 & 6 & 0,0176 & 1,5322 \\
\hline GHL & 2.05 .2013 & 2 & $-0,0039$ & $-3,4339 * *$ \\
\hline HHA & 21.11.2013 & 2 & $-0,0075$ & $-6,6502 * *$ \\
\hline HHD & 21.11 .2013 & 2 & $-0,0005$ & $-0,7108$ \\
\hline HHM & 2.12 .2013 & 5 & $-0,0736$ & $-7,3974 * *$ \\
\hline $\mathrm{HHN}$ & 21.11 .2013 & 4 & $-0,0250$ & $-6,2270^{* *}$ \\
\hline KEA & 22.07 .2014 & 2 & $-0,0004$ & $-0,6272$ \\
\hline KEB & 16.07 .2014 & 2 & $-0,0028$ & $-4,5863 * *$ \\
\hline $\mathrm{KEF}$ & 16.07 .2014 & 6 & 0,0184 & 1,5703 \\
\hline KEG & 16.07 .2014 & 4 & $-0,0192$ & $-8,9129 * *$ \\
\hline $\mathrm{KEH}$ & 16.07 .2014 & 5 & $-0,0639$ & $-7,8921 * *$ \\
\hline KEK & 23.07 .2014 & 3 & $-0,0126$ & $-3,6604 * *$ \\
\hline MHA & 28.02 .2014 & 2 & $-0,0019$ & $-2,3699 * *$ \\
\hline MHS & 13.01 .2014 & 3 & $-0,0115$ & $-4,6011 * *$ \\
\hline VEA & 15.02 .2012 & 3 & $-0,0113$ & $-7,3001 * *$ \\
\hline VEB & 23.02 .2012 & 4 & $-0,0221$ & $-5,8955^{* *}$ \\
\hline VER & 30.04 .2013 & 2 & $-0,0063$ & $-5,1857 * *$ \\
\hline VEY & 27.10 .2010 & 4 & $-0,0211$ & $-5,9068^{* *}$ \\
\hline VGA & 24.09 .2013 & 5 & 0,0143 & 1,2561 \\
\hline VGB & 1.03 .2010 & 2 & $-0,0068$ & $-6,3320 * *$ \\
\hline
\end{tabular}




\begin{tabular}{|c|c|c|c|c|}
\hline ZHA & 1.07 .2011 & 2 & $-0,0015$ & $-2,7640^{* *}$ \\
\hline ZHN & 17.09 .2013 & 6 & 0,0185 & 1,5699 \\
\hline ZHT & 30.04 .2013 & 2 & $-0,0033$ & $-4,4101^{* *}$ \\
\hline
\end{tabular}

Not: **\% 5 seviyesinde istatistiksel olarak anlamlı

Altın oranı yoğun olan 9 katılım esasına dayalı emeklilik yatırım fonunun (AEA, AEL, HEA, AGA, BNA, GHA, KEF, VGA, ZHN) anormal getirileri (AR) pozitiftir. Varlık türü çeşitliliğinde $\% 75$ ve üzerinde kira sertifikaları oranına sahip (AGD, AGT, GES, HHD, KEA) 5 katılım esasına dayalı emeklilik yatırım fonun AR değerleri negatiftir. Varlık türü çeşitliliğinde \%50-\%75 arasında kira sertifikaları oranına sahip 26 katılım esasına dayalı emeklilik yatırım fonunun AR değerleri ise istatistiksel olarak anlamlı ve negatiftir. Bu sonuç politik krizin varlık türü kira sertifikalarına dayalı katılım esasına dayalı emeklilik yatırım fonlarının getirilerini olumsuz etkilediğini göstermiştir. Tablo 12 de yer alan sonuçlar, krizlerin katılım esasına dayalı emeklilik yatırım fonlarının getirisi üzerindeki etkisini test eden beş numaralı hipotezin reddedildiğini göstermektedir. Tablo 13'de görüldüğü üzere 15.07.2016 tarihinde gerçekleşen politik olayın fonların ortalama anormal getirisi (AAR) üzerindeki etkisi 19.07.2016 tarihinde $(\mathrm{t}+2)$ istatiksel olarak anlamlı ve negatif gözlenmiştir $(\mathrm{AAR}=-0.0077, \mathrm{t}$ istatistiği $=$ 2.2379).

Tablo 13. Politik Kriz Öncesi ve Sonras1

\begin{tabular}{|c|c|c|c|}
\multicolumn{2}{|c|}{ Ortalama Anormal Getiri (AAR } \\
\hline Tarih & & AAR & t istatistiği \\
\hline 28.06 .2016 & $\mathrm{t}-10$ & 0.0026 & $5.1800^{* *}$ \\
\hline 29.06 .2016 & $\mathrm{t}-9$ & -0.0008 & -0.4449 \\
\hline 30.06 .2016 & $\mathrm{t}-8$ & -0.0011 & $-8.1097^{* *}$ \\
\hline & & & \\
01.07 .2016 & $\mathrm{t}-7$ & -0.0021 & $-5.9455^{* *}$ \\
\hline & & & \\
04.07 .2016 & $\mathrm{t}-6$ & 0.0053 & $8.3605^{* *}$ \\
\hline & & & \\
\hline 08.07 .2016 & $\mathrm{t}-5$ & 0.0010 & $4.5969^{* *}$ \\
\hline & & & \\
11.07 .2016 & $\mathrm{t}-4$ & 0.0069 & $3.7663^{* *}$ \\
\hline 12.07 .2016 & $\mathrm{t}-3$ & 0.0006 & 1.0130 \\
\hline
\end{tabular}




\begin{tabular}{|l|c|c|c|}
\hline 13.07 .2016 & $\mathrm{t}-2$ & -0.0008 & -0.8483 \\
\hline 14.07 .2016 & $\mathrm{t}-1$ & -0.0005 & -1.3594 \\
\hline $\mathbf{1 5 . 0 7 . 2 0 1 6}$ & $\mathbf{t ~ 0}$ & $\mathbf{- 0 . 0 0 1 6}$ & $\mathbf{- 1 . 5 2 1 9}$ \\
\hline 18.07 .2016 & $\mathrm{t}+1$ & -0.0002 & -0.8051 \\
\hline $\mathbf{1 9 . 0 7 . 2 0 1 6}$ & $\mathbf{t}+\mathbf{2}$ & $\mathbf{- 0 . 0 0 7 7}$ & $\mathbf{- 2 . 2 3 7 9 * *}$ \\
\hline 20.07 .2016 & $\mathrm{t}+3$ & 0.0010 & 1.0158 \\
\hline 21.07 .2016 & $\mathrm{t}+4$ & -0.0015 & -1.5788 \\
\hline 22.07 .2016 & $\mathrm{t}+5$ & -0.0040 & -1.6775 \\
\hline 25.07 .2016 & $\mathrm{t}+6$ & 0.0008 & 1.4350 \\
\hline 26.07 .2016 & $\mathrm{t}+7$ & 0.0024 & 1.2245 \\
\hline 27.07 .2016 & $\mathrm{t}+8$ & -0.0005 & $-2.5863^{* *}$ \\
\hline 28.07 .2016 & $\mathrm{t}+9$ & 0.0026 & $4.2164 * *$ \\
\hline & & & \\
\hline 29.07 .2016 & $\mathrm{t}+10$ & 0.0024 & $4.8186^{* *}$ \\
\hline
\end{tabular}

Not: ** \% 5 seviyesinde istatistiksel olarak anlamlı

\subsubsection{Katılım Bankacılığı Esasına Dayalı Fonları Yönetenlerin Seçicilik Ve Piyasa Zamanlama Yeteneğinin Analizi}

Treynor-Mazuy tarafından geliştirilen fon yöneticisinin fon varlık fonunun çeşitliliğinin seçiminin ve fon yöneticisinin piyasa zamanlama yeteneğinin belirlendiği regresyon modeli aşağıdaki gibidir.

$$
R_{p}-R_{f}=\alpha+\beta=\left(R_{m}-R_{f}\right)+C *\left(R_{m}-R_{f}\right)^{2}+\varepsilon_{p}
$$

Modelde $\alpha$ katsayısı fon yöneticinin varlık seçimindeki başarısını, $\beta$ katsayısı fonun sistematik riskini, C katsayısı da fon yöneticisinin zamanlama yeteneğini göstermektedir. 
Tablo 14. Kuadratik Regresyon Modeli ile Belirlenen Fonların Yöneticilerinden Piyasa Zamanlama Yeteneğine Sahip Fonlar (BIST 100 ve 40 Fonun Ortalama Getiri Endeksine Göre Belirlenmiş)

\begin{tabular}{|c|c|c|c|c|c|c|c|c|c|}
\hline $\begin{array}{c}\text { Fon } \\
\text { Kodu }\end{array}$ & $\begin{array}{c}\text { C } \\
\text { Katsay1s1/ } \\
\text { BIST100 }\end{array}$ & $\begin{array}{c}\text { Sira } \\
\text { No }\end{array}$ & $\begin{array}{c}\text { İstatistik } \\
\text { değeri (t) }\end{array}$ & $\begin{array}{c}\text { Olas1lik } \\
\text { Değeri/ } \\
\text { sign }\end{array}$ & $\begin{array}{c}\text { Fon } \\
\text { Kodu }\end{array}$ & $\begin{array}{c}\text { C } \\
\text { Katsay1s1/ } \\
\text { ORT_FON }\end{array}$ & $\begin{array}{c}\text { Sira } \\
\text { No }\end{array}$ & $\begin{array}{c}\text { İstatistik } \\
\text { değeri (t) }\end{array}$ & $\begin{array}{c}\text { Olasıllk } \\
\text { Değeri/ sign }\end{array}$ \\
\hline KEF & 0,5670 & 1 & 0,5424 & 0,5877 & HEA & 9,2737 & 1 & 3,7820 & $0,0002^{* * *}$ \\
\hline ZHN & 0,5542 & 2 & 0,5242 & 0,6002 & AEA & 9,1252 & 2 & 3,5635 & $0,0004^{* * *}$ \\
\hline AEL & 0,5487 & 3 & 0,5225 & 0,6014 & ZHN & 8,9452 & 3 & 3,3826 & $0,0007^{* * *}$ \\
\hline AGA & 0,5444 & 4 & 0,5131 & 0,6080 & GHA & 8,8545 & 4 & 3,4121 & $0,0007^{* * *}$ \\
\hline BNA & 0,5408 & 5 & 0,5054 & 0,6134 & KEF & 8,7436 & 5 & 3,3676 & $0,0008^{* * *}$ \\
\hline AEA & 0,5266 & 6 & 0,5063 & 0,6128 & VGA & 8,1870 & 6 & 3,2941 & $0,0010^{* * *}$ \\
\hline VGA & 0,4813 & 7 & 0,4638 & 0,6429 & BNA & 8,1090 & 7 & 3,0377 & $0,0024 * * *$ \\
\hline GHA & 0,4712 & 8 & 0,4517 & 0,6515 & AGA & 8,0168 & 8 & 3,0159 & $0,0026^{* * *}$ \\
\hline HEA & 0,3969 & 9 & 0,3942 & 0,6935 & AEL & 7,2000 & 9 & 2,7164 & $0,0067^{* * *}$ \\
\hline & & & & & AGM & 2,6604 & 10 & 3,4677 & $0,0005^{* * *}$ \\
\hline
\end{tabular}

Not: *\%10 seviyesinde, $* * \% 5$ seviyesinde, $* * * \% 1$ seviyesinde istatistiksel olarak anlaml

Fon yöneticilerinin piyasa zamanlama yeteneklerine baktığımızda, incelediğimiz 40 fondan sadece 10'unun C katsayısının pozitif değere sahip olduğu tespit edilmiştir. Piyasa getirisi olarak BIST 100 endeksi baz alındığında sadece 9 fonun yöneticisinin piyasa zamanlama yeteneğinin olduğu, piyasa getirisi olarak 40 fonun ortalama getirisi baz alındığında ise sadece 10 fonun piyasa zamanlama yeteneğinin olduğu sonucuna ulaşılmıştır. Tablo 14 'de gösterildiği üzere BIST 100 endeksine göre hesaplanan C katsayılarından 40 fondan 19'unun istatistiksel olarak anlamlı olduğu, istatiksel olarak anlamlı olan fonların fon yöneticilerinin piyasa zamanlama yeteneklerinin olmadığ 1,40 fonun ortalama getiri endeksine göre hesaplanan C katsayılarından 37 fonun istatiksel olarak anlamlı olduğu ve 40 fon içerisinden 10 fonun yöneticisinin piyasa zamanlama yeteneği olduğu görülmüştür. $C$ katsayısının pozitif çıktığı fonlar altın varlık türü oran $\% 50$ inin üzerinde olan fonlardır. Bu sonuç pozitif getiri sağlayan fonların tesadüfi olarak performanslarının iyi olmadığ 1 , bu fonları yöneten yöneticilerin seçicilik ve piyasa zamanlaması yeteneğine sahip olduğu şeklinde yorumlanmıştır.

\section{SONUÇ}

Araştırma kapsamında Türkiye'de katılım esasına dayalı 40 emeklilik yatırım fonunun 01.08.2014-28.02.2019 tarihleri arasındaki performansları analiz edilmiştir. Analizlerde ilk olarak, aynı tür yoğunluğuna sahip katılım esasına dayalı emeklilik fonlarının performansları arasında anlamlı bir fark olup olmadığ 1 test edilmiştir. Altın ve kira sertifikası yoğun fonların performansları arasında 
istatiksel olarak anlamlı bir farklılık bulunmuştur. İkinci olarak, kamu şirketleri ve özel şirketler tarafından yönetilen katılım esasına dayalı emeklilik yatırım fonlarının performansları arasında anlamlı farklılık olup olmadığı analiz edilmiş, istatistiksel olarak anlamlı farklılık bulunmamıştır. Üçüncü olarak 11 farklı fon şirketi tarafından yönetilen katılım esasına dayalı emeklilik yatırım fonlarının performansları arasında anlamlı farklılık olup olmadığı analiz edilmiş, istatistiksel olarak anlamlı farklılık bulunmamıştır. Dördüncü olarak, risk seviyelerine göre katılım esasına dayalı emeklilik yatırım fonlarının performansları arasında anlamlı farklılık olup olmadığı analiz edilmiş, risk grubuna göre ayrılmış fon performansları arasında anlamlı farklılık olduğu tespit edilmiştir.

Analizlerin devamında, 15.07.2016 tarihinde gerçekleşen politik krizden, katılım esasına dayalı emeklilik yatıım fonlarının etkilenip etkilenmediği olay etüdü yöntemiyle analiz edilmiş, bu politik olay sonrasında 40 fondan 26'sında istatiksel olarak anlamlı negatif anormal getiri oluştuğu tespit edilmiştir. $\mathrm{Bu}$ durum katılım esasına dayalı fonların krizden etkilendiği şeklinde yorumlanmıştır. Ayrıca altın yoğun katılım esasına dayalı emeklilik yatırım fonlarının krizde değer kaybetmediği ve altının kriz dönemlerinde güvenli bir liman olduğu tespit edilmiştir. Ülkenin ekonomik, politik ve sosyal yapısı kira sertifikasına ait temel risklerden birini oluşturmaktadır. Kira sertifikasına dayalı sermaye piyasası araçlarından oluşan emeklilik fonlarının politik krizden olumsuz etkilendiği analiz sonuçları ile tespit edilmiştir.

Sonuç olarak altına dayalı sermaye piyasası araçlarından oluşan emeklilik yatırım fonlarının başarılı performansa sahip olduğu ve kriz durumlarında değer kaybetmediği tespit edilmiştir. Kira sertifikasına dayalı sermaye piyasası araçlarından oluşan fonların ise performanslarının kötü olduğu ve krizlerden olumsuz etkilendiği görülmüştür. Portföy yöneticilerinin piyasa zamanlaması ve seçicilik konusunda ise basarısız olduğu test edilmiştir. Faiz getirisi istemeyen bireysel yatırımcıların tasarruflarının emeklilik yatırım fonlarında kalıcı olarak tutulmasının sağlanması için fon yöneticilerinin doğru portföy çeşitliliği yapması gerektiği ve sermaye piyasalarında daha fazla çeşitlilikte finansal enstrümanın işlem görmeye başlaması gerektiği önerilmiştir. 


\section{KAYNAKLAR}

Abdullah, Fikriyah-Hassan,Taufiq-Mohamed, Shamsher (2007), "Investigation of ThePerformanceof Malaysian Islamic Unit Trust Funds: Comparison With Conventional Unit Trust Funds", Managerial Finance, 33(2), pp.142-153.

Akel, Veli (2007), “Türkiye'deki A ve B Tipi Yatırım Fonları Performansının Devamlılığının Parametrik ve Parametrik Olmayan Yöntemlerle Değerlendirilmesi”, Dokuz Eylül Üniversitesi İktisadi ve İdari Bilimler Dergisi, 22(2), ss.147-177.

Ayaydın, Hasan (2013), “Türkiye'deki Emeklilik Yatırım Fonlarının Performanslarının Analizi”, Çukurova Üniversitesi Sosyal Bilimler Enstitüsü Dergisi, 22(2), ss.59-80.

Baykara, Büşra (2018), "İslami Yatırım Fonları ve Türkiye'de İslami Yatırım Fonlarının Geleneksel Fonlarla Karşılaştırılmalı Analizi”, Yüksek Lisans Tezi, Ufuk Üniversitesi Sosyal Bilimler Enstitüsü, Ankara.

Boo, YeeLing- Ee, MongShan - Li, Bob-Rashid, Mamunur (2017), "Islamicor Conventional Mutual Funds: Who Has the Upper Hand? Evidence from Malaysia”, Pacific-Basin Finance Journal, 42(1), pp.183-192.

Brown, Stephen J.- Warner, Jerold B. (1985), "Using Daily StockReturns, The Case of EventStudies", Journal of Financial Economics, 14, pp.3-31.

Dalğar, Hüseyin (2006),“Kurumsal Yatırımcılar Olarak Emeklilik Yatırım Fonları ve Performanslarının Değerlendirilmesi”, Türkiye Bankalar Birliği Yayınları, İstanbul.

Henriksson, Roy D. (1984), "Market Timing and Mutual Fund Performance: An Empirical Investigation”, Journal of Business, 57(1), pp.73-96.

Jensen, Michael C. (1968), "The Performance of MutualFund in the Period 19451964", TheJournal of Finance, 23(2), pp.389-416.

Kalkan, Hakan (1994), “Türk Yatırım Fonlarının Performansı: Deneysel Bir Araştırma", Yüksek Lisans Tezi, Bilkent Üniversitesi İşletme Enstitüsü, Ankara. 
Karabacak, Serkan Ahmet (2015), "Bireysel Emeklilik Sistemi, Finansal Açıdan Değerlendirilmesi ve Oyak Modeli Uygulaması", Yüksek Lisans Tezi, Gazi Üniversitesi Sosyal Bilimler Enstitüsü, Ankara.

Karacabey, Argun A. (1999), “A Tipi Hisse Senedi Fonlarının Performanslarının Değerlendirilmesi”, Kara Harp Okulu Bilim Dergisi, 2(1), ss.84-99.

Kılıç, Saim (2002),“Türkiye'deki Yatırım Fonlarının Performanslarının Değerlendirilmesi”, Yüksek Lisans Tezi, Ankara Üniversitesi Sosyal Bilimler Enstitüsü, Ankara.

Kızılgeçit, Zeynep (2014), "Bireysel Emeklilik Sistemi ve Bireysel Emeklilik Sistemindeki Sigorta Şirketlerinde Fon Yönetimi”, Yüksek Lisans Tezi, Atatürk Üniversitesi Sosyal Bilimler Enstitüsü, Erzurum.

Korkmaz, Turhan-Uygurtürk, Hasan (2007), “Türk Emeklilik Fonlarının Performans Ölçümünde Regresyon Analizinin Kullanılması”, Zonguldak Karaelmas Üniversitesi Sosyal Bilimler Dergisi,3(5), ss.37-52.

Kurun, Engin(2005), "Faiz Riski Yönetimi ve Türkiye Uygulaması", Sermaye Piyasası Kurulu Yayınları, Ankara.

Mansor, Fadillah-Bhatti, M.Ishaq (2011), "The Islamic Mutual Fund Performance: New Evidence On Market Timing And Stock Selectivity", Paper presented at 2011 International Conference on Economicsand Finance Research, 4(1),ss.487-494.

Markowitz, Harry(1952),“Portfolio Selection”, Journal of Finance,7(1), ss. 77-91.

McDonald, John G. (1973), "French Mutual Fund Performance; Evaluation of Internationally-DiversifiedPortfolios", Journal of Finance,28(5), ss.11611180 .

Merdad, Hesham- Hassan, M. Kabir-Alhenawi, Yasser (2010), "Islamic Versus Conventional Mutual Funds Performance in Saudi Arabia: A Case Study", Islamic Econ,23(2),ss.157-193. 
Metin, Okan (2018), “Aktif Olarak Yönetilen ve Pasif Olarak Yönetilen Yatırım Fonlarının Performanslarının Değerlendirilmesi”, Yüksek Lisans Tezi, Nuh Naci Yazgan Üniversitesi Sosyal Bilimler Enstitüsü, Kayseri.

Saleck, Cheikh (2018), "Yatırım Fonları Risk ve Getiri Analizi: Türkiye Üzerine Bir Uygulama", Yüksek Lisans Tezi, Dokuz Eylül Üniversitesi Sosyal Bilimler Enstitüsü, İzmir.

Shah, IrfanUllah-Iqbal, Junaid-Malik, MuhammadFaizan (2012), "Comparative Valuation Between Islamic and Conventional Mutual Fund", International ResearchJournal of Finance andEconomics, 96 (1),pp.28-33.

Sharpe, William F. (1966), "MutualFundPerformance", The Journal of Business, 39(1),pp.119-138.

Taşcıyan, Kamer Hagop (2009),“Emeklilik Yatırım Fonları Performanslarının Klasik Performans Ölçüm Yöntemleri ve Veri Zarflama Analizi ile Değerlendirilmesi”, Yüksek Lisans Tezi, Kadir Has Üniversitesi Sosyal Bilimler Enstitüsü, İstanbul.

Tekbaş, Mehmet Şükrü-Köse, Ahmet- Sarıkovanlık, Vedat-Sarıŏlu, Serra ErenBaş, NazlıKalfa -Özdemir, Kerem (2014),“Temel Finans Matematiği ve Değerleme Yöntemleri”, Sermaye Piyasası Lisanslama Sicil ve Eğitim Kuruluşu A.Ş. Yayınları, Ankara.

Tezcan, Hasan Çağatay (2012), "Performance Evaluation of TurkishPensionFunds: Selectivity, Market TimingandPersistence", Yüksek Lisans Tezi, Koç Üniversitesi Sosyal Bilimler Enstitüsü, İstanbul.

Treynor, Jack L. (1965), "How to Rate Management of InvestmentFund", Harvard Business Review,43(1), pp.63-75.

Treynor, Jack L.-Mazuy, Kay K. (1966),“Can MutualFundsOutguessThe Market?”, Harvard Business Review. 44(4), pp.131-136.

Turan, Ayten (2005).“Türkiye'de Emeklilik Yatırım Fonları ve Performans Değerlendirmesi”, Yüksek Lisans Tezi, Karadeniz Teknik Üniversitesi Sosyal Bilimler Enstitüsü, Trabzon. 
Uysal, Mustafa-Adalı, Zafer (2018), “Türkiye'deki Emeklilik Yatırım Fonlarının Performans Ölçümü: İslami Emeklilik Yatırım Fonları ile Geleneksel Emeklilik Yatırım Fonlarının Performans Karşılaştırması", Fiscaoeconomia, 2(2), pp.50-73.

\section{İnternet Kaynakları:}

http://spk.gov.tr/Sayfa/Dosya/1205,( 13.06.2019).

http://www.resmigazete.gov.tr/eskiler/2008/01/20080112-8.htm , (13.06.2019).

http://www.resmigazete.gov.tr/eskiler/2012/12/20121229-7.htm,(13.06.2019).

https://www.egm.org.tr/bireysel-emeklilik/emeklilik-yatirim-fonlari/, (13.06.2019). 
